\title{
Prospective Speculation for Safe Reuse of Agricultural Drainage Water in Irrigation
}

\author{
I. H. Elsokkary ${ }^{1}$ and A. F. Abukila ${ }^{2}$
}

\begin{abstract}
The main and almost exclusive source of surface fresh water in Egypt is the River Nile. It is obvious that the Nile water agreement with Sudan in 1959 had defined Egypt's budget by 55.5 billion cubic meter per year, of which $84 \%$ is used by the agricultural sector. Of the greatest interest is the quality of Nile water in Egypt has been changed after the construction of Aswan High Dam (AHD) in 1968 and the water became silt free even at the annual flood season. At present, the major challenge that facing Egypt is how to meet the water demand for food production and also to protect Nile water from pollution. According to water quality impact assessment study carried out since 1990, the water quality of Nasser Lake was deemed good and the water quality of Nile River downstream AHD has reflected the quality of the water of Nasser Lake. However, significant changes were recorded in the water along the main stem of the river between Aswan and Delta Barrage because of discharge of agricultural drainage water in Nile stream. The water quality of most of these drains were not complying with the standards set by law 48/1982 (Art. 65) regulating the quality of drainage water which can be mixed with fresh water. However, significant amounts of organic load were biodegraded and the level DO increased from $4 \mathrm{mg} / \mathrm{l}$ at Aswan to 9-10 $\mathrm{mg} / \mathrm{l}$ at $200 \mathrm{Km}$ downstream Aswan. Currently, the concentration levels of TDS increased from $150 \mathrm{mg} / /$ at Aswan 250mg/l near Cairo. As a result, the water quality between Aswan and Delta Barrage is considered of good quality.

The waters of Damietta and Rosetta Branches of Nile Delta receive high loads of biological, inorganic and organic compounds and consequently are characterized by low quality water. In general, the water of Rosetta Branch is highly polluted than that of Damietta Branch. Of great concern is the water of the agriculture drains which discharge in River Nile; the main stem and delta branches. These drains receive, in addition to agriculture seeping, domestic and industrial effluents from point sources and diffuse sources. As a result, the water quality of these drains did not comply with law 48/1982 (Art. 65). The sources of water of the collected main drain are the small drains, which receive un-treated domestic and industrial effluents from villages and small communities. In order to improve the water quality of the main drain to cope with standards of law 48/1982, the water of the small drain
\end{abstract}

should be treated before discharging into the main collector drain. This treatment should be designed at the point sources just before entering the main drain. It is well known that villages in Egypt are still without sanitation facilities and construction of conventional wastewater treatment plants is not applicable and expensive. This makes the non-conventional treatment system are most acceptable. Of these is the in-stream wetlands treatment system which has several advantages such as the treatment efficiency is high, requires low capitals investment, and easy operation and maintenance.

Keywords: Nile River, Drainage water, Wetlands, Pollution, COD, BOD 5 , DO.

\section{INTRODUCTION}

Water Scarcity and lack of acceptable water quality are the most serious challenges in the twenty-first century. According to FAO (1992), low quality water is defined as "water that possesses certain characteristics which have the potential to cause problems when it is used for an intended purpose". Thus, optimizing the management of available fresh water and controlling water pollution are being major issues to preserve water under good conditions for future generations On world wide scale, it seems that no river no lake and no part of the oceans is entirely free from pollution (Dybern, 1974). This may be due to integration of several causes such as increasing population growth, industrial production, mis-use of land and water for food production, lack of knowledge how the natural environment is built up and function, and lack of money for pollution abatement and prevention (Bouwer, 2002). Under such circumstances, Egypt is a country facing both water scarcity and deterioration of the quality of water of Nile River for irrigation use and for other purposes.

It is obvious that the main source of surface fresh water in Egypt is the Nile River. According to Nile water agreement of 1959 between Egypt and Sudan, Egypt's share of water is limited by 55.5 billion cubic meter per year. Agriculture use accounts by $84 \%$ of this quantity, while industrial, municipal and navigation use account by 8, 5 and 3\%, respectively (Abu Zeid, 1992).

\footnotetext{
${ }^{1}$ Department of Soil and Water Sciences, Faculty of Agricultural, El-Shatby- Post Code:21545, Alexandria University,

Alexandria, Egypt

E-mail address: elsokkary35@gmail.com

${ }^{2}$ National Water Research Center, Drainage Research institute,

Egypt El-Qanater El-Khairiya post code:13621

E-mail address: Alaafg@gmail.com

Received June 2, 2012, Accepted June 30,, 2012
} 
At downstream old Aswan Dam, the quality of Nile water, on the basis of salinity, is good for irrigation use with slight monthly variation in salinity, varying from 93 to $165 \mathrm{mg} / \mathrm{l}$ (Whittingtan and Guariso, 1983). According to Ball (1939), salinity of Nile water at Cairo, during the period 1915-1936, recorded salinity levels between 115 and $217 \mathrm{mg} / \mathrm{l}$ (Table 1), with slight variations in the concentrations of water soluble ions (Table 2). It has been reported also that appreciable amounts of elements had entered the Nile River from agricultural drains
(Tables 3 and 4) which indicates earlier contamination of the water of Nile River by agricultural chemicals (Ball, 1939). Due to natural dilution regime occurring along the river stream, these chemicals did not adversely influence the quality of Nile water at that time. Another factor, which had eliminated the effect of these disposed chemicals on water quality, is the seasonal Nile flood, as expressed by total suspended matter (Table 5) or turbidity (Tables 6) which acted for flushing the river body and cleanse water from these additives.

Table 1. Average values of the concentration of total dissolved solids $(\mathrm{mg} / \mathrm{l})$ in water of Nile River at Cairo in the period 1915- 1936 (Ball, 1939 ) and in 1963 (El-Gamal and Shafik, 1985)

\begin{tabular}{cccccc}
\hline Month & $\mathbf{1 9 1 5 - 1 9 3 6}$ & $\mathbf{1 9 6 3}$ & Month & $\mathbf{1 9 1 5 - 1 9 3 6}$ & $\mathbf{1 9 6 3}$ \\
\hline Jan. & 162 & 190 & July & 200 & 210 \\
\hline Feb. & 115 & 199 & Aug. & 140 & 167 \\
\hline Mar. & 196 & 200 & Sept. & 138 & 172 \\
\hline Apr. & 216 & 191 & Oct. & 132 & 167 \\
\hline May & 217 & 192 & Nov. & 138 & 175 \\
\hline June & 212 & 182 & Dec & 154 & 170 \\
\hline
\end{tabular}

Table 2. Average values of the concentration of water soluble ions $(\mathrm{mg} / \mathrm{l})$ in Nile River at Cairo city at different times (Ball, 1939 )

\begin{tabular}{cccccc}
\hline \multirow{2}{*}{ Ions } & \multirow{2}{*}{$\mathbf{1 8 8 0}$} & \multirow{2}{*}{$\mathbf{1 9 0 6}$} & \multirow{2}{*}{$\mathbf{( 1 9 2 4 - 1 9 2 7 )}$} & \multicolumn{2}{c}{ (1906-1936) } \\
\cline { 5 - 6 } & & & & Aug.-Nov. & Dec.-July \\
\hline $\mathrm{Ca}$ & 15.9 & 14.7 & 23.6 & 23.6 & 28.8 \\
\hline $\mathrm{Mg}$ & 8.8 & 11.3 & 6.9 & 6.9 & 8.8 \\
\hline $\mathrm{Na}$ & 15.6 & 2.6 & 3.7 & 3.7 & 5.5 \\
\hline $\mathrm{K}$ & 3.9 & 7.5 & 5.1 & 5.1 & 16.4 \\
\hline $\mathrm{Cl}$ & 3.4 & 5.4 & 7.7 & 7.7 & 11.4 \\
\hline $\mathrm{SO}_{4}$ & 4.7 & 11.6 & 12.4 & 12.4 & 13.2 \\
\hline $\mathrm{SiO}_{2}$ & 20.1 & &
\end{tabular}

Table 3. Average concentration of water soluble ions and O.M. $(\mathrm{mg} / \mathrm{l})$ entering the water of Nile River at Cairo in the periods 1924-1927 and 1936 (Ball, 1939)

\begin{tabular}{cccccc}
\hline Element & $\mathbf{1 9 2 4 - 1 9 2 7}$ & $\mathbf{1 9 6 3}$ & Element & $\mathbf{1 9 2 4 - 1 9 2 7}$ & $\mathbf{1 9 6 3}$ \\
\hline $\mathrm{Ca}$ & 15.7 & 28.8 & $\mathrm{Cl}$ & 7.5 & 16.4 \\
\hline $\mathrm{Mg}$ & 4.6 & 8.8 & $\mathrm{SO}_{4}$ & 5.4 & 11.4 \\
\hline $\mathrm{Na}$ & 11.3 & 25.2 & $\mathrm{SiO}_{2}$ & 11.6 & 13.2 \\
\hline $\mathrm{K}$ & 2.6 & 5.5 & $\mathrm{O}$. & 1.4 & 1.7 \\
\hline
\end{tabular}

Table 4. The quantity (tons) of various constituents entered the Nile River from agricultural drainage water (Ball, 1939)

\begin{tabular}{ccccc}
\hline \multirow{2}{*}{ Constituents } & \multicolumn{4}{c}{ Year } \\
\cline { 2 - 5 } & $\mathbf{1 9 0 6}$ & $\mathbf{1 9 1 6}$ & $\mathbf{1 9 2 6}$ & $\mathbf{1 9 3 6}$ \\
\hline $\mathrm{Ca}$ & - & - & 411 & 3411 \\
\hline $\mathrm{Na}$ & 189 & 348 & 3110 & 3732 \\
\hline $\mathrm{NH}_{4}$ & 13 & 48 & 63 & 1221 \\
\hline $\mathrm{CO}_{3}$ & - & - & - & 999 \\
\hline $\mathrm{NO}_{3}$ & 510 & 939 & 9684 & 21198 \\
\hline $\mathrm{SO}_{4}$ & 33 & 126 & 168 & 1539 \\
\hline
\end{tabular}


Table 5. Average values of the concentration (mg/l) of total suspended matter (TSM) in River Nile at Cairo at $0.5 \mathrm{~m}$ depth in mid stream during the period 1913-1932 (Ball, 1939)

\begin{tabular}{cccc}
\hline Month & TSM & Month & TSM \\
\hline Jan. & 95 & July & 43 \\
\hline Feb. & 52 & Aug. & 976 \\
\hline Mar. & 36 & Sept. & 1411 \\
\hline Apr. & 32 & Oct. & 390 \\
\hline May & 28 & Nov. & 171 \\
\hline June & 29 & Dec & \\
\hline
\end{tabular}

Table 6. Monthly chemical analysis of the water of Nile River at Cairo during the year $\mathbf{1 9 6 3}$ (El-Gamal and Shafik, 1985)

\begin{tabular}{ccc}
\hline Month & Turbidity (Silica Scale) & TDS (mg/l) \\
\hline Jan. & 125 & 190 \\
\hline Feb. & 65 & 199 \\
\hline Mar. & 26 & 200 \\
\hline Apr. & 25 & 191 \\
\hline May & 20 & 192 \\
\hline June & 26 & 182 \\
\hline July & 910 & 210 \\
\hline Aug. & 950 & 167 \\
\hline Sept. & 6935 & 172 \\
\hline Oct. & 2550 & 167 \\
\hline Nov. & 500 & 175 \\
\hline Dec & 340 & 170
\end{tabular}

After the construction of Aswan high Dam (AHD) in 1968, the quality of Nile water had been changed. Because of the continuous increase of agricultural, domestic and industrial discharging in the river beside the absence of suspended matter of seasonal flood, water pollution progressively increased to an extent considered to be a serious problem affecting water quality. By time proceeding, pollutants have been accumulated in the river body and there were rapid drastic changes in water quality which could influence its future use for the intended purposes.

\section{REVIEW OF REGULATIONS AND STANDARDS}

Wastewater that is mostly entering the Nile River and causes degradation of Nile water quality is becoming major issue in Egypt. This enabled the Egyptian authorities to enact numbers of laws in order to protect the Nile water from pollution (MAB, 1983). The law 48 was issued in 1982 in order to protect The River Nile and waterways from pollution. Soon after, the Ministry of Public Works and Water Resources (MPWWR) issued the decree No. 8 in 1983 to be the implement regulation of the law 48/1982 (RNPDP, 1995). This decree was built on reviewing both law 93/1962 concerning the discharge of liquids and wastes, law 38/1976 concerning public hygiene, law 74/1971 concerning irrigation and drainage, and law 48/1982 concerning the protection of River Nile and waterways from pollution.

It is clearly understood from Decree 8/1983 that only that treated effluents are allowed permeation to discharge to waterways. It also states that the representatives of MPWWR, MOH (Ministry of Health), and concerned Sanitary Drainage Agency have full rights to enter all permitted establishments at any time for periodic and non- periodic sampling and inspection of facilities.

The implementing Decree 8 of 1983 specifies the water quality standards for the following categories; (i) Nile River and canals into which discharges are licensed (Art. 60); (ii) treated industrial discharges to Nile River, canals and groundwater: upstream Delta Barrage discharging more than $100 \mathrm{~m}^{3} /$ day (Art. 61), downstream Delta Barrage discharging more than 100 $\mathrm{m}^{3} /$ day (Art. 61), upstream Delta Barrage discharging less than $100 \mathrm{~m}^{3} /$ day (Art. 62), downstream Delta Barrage discharging less than $100 \mathrm{~m}^{3} /$ day (Art. 62); (iii) drain water to be mixed with the water of the Nile River or canals (Art. 65); (iv) treated industrial and sanitary waste discharges to drains, lakes and ponds (Art. 66); and (v)drains, lakes and ponds which discharges are licensed (Art. 68).

The Decree 8/1983 stated also that the discharge of treated sanitary effluents to Nile River and canals is not 
allowed to all (Art. 63), and any discharge of sanitary into other water bodies should be chlorinated (Art. 67). In addition, the use of agrochemicals for weed control is also regulated in the law (Art. 11).

The Egyptian Environmental Affairs Agency (EEAA) is responsible for protection of the environment in general. The law 4/1994 stated that with respected to the pollution of the water and environment, the law 48/1982 is not affected and the MWRI remains the responsible authority for water quality and water pollution issues, although the definition of "discharge" in law 4/1994 specifically includes discharges to the Nile River and waterways. It has been proved that EEAA is responsible for coordinating the pollution monitoring networks.

Recently, the Ministry of Housing Utilities and New Communities (MHUNC) with the agreement of Ministry of Health and Population (MOHP) issued the Mistrial Decree 44/2000, concerning Amendment of the Executive Regulation of the law 93/1962 Pertaining Discharging liquid Effluent. The decree strongly opposes the use of wastewater in irrigation of vegetables, fruits, and other crop possibly eaten raw.

According to the law 48/1982 and Decree 8/1983, the limits of microbiological parameters for discharging effluent to different water bodies are: 2500, 2500, 5000, and $5000 \mathrm{MPN} / 100 \mathrm{ml}$ for River Nile, Nile branches, main canals, ditches and groundwater reservoirs, drains and brackish or saline water, respectively.

\subsection{Responsibilities For Water Quality Management}

Ministries involved for operational, research, monitoring and regulation purposes and management for water quality of Nile River are: Ministry of Water Resources and Irrigation (MWRI), Egyptian Environmental Affairs Agency (EEAA), Ministry of Health and Population (MOHP), Ministry of Housing, Utilities and New Communities (MHUNC), Ministry of Agriculture and Land Reclamation (MALR), Ministry of Industry (MOI), Ministry of Higher Education and Scientific Research (MHESR), Ministry of Interior.

The objectives of the present article, therefore, were to evaluate (i) the water quality of Nile River and agricultural drains and (ii) the efficiency of non conventional constructed in-stream wetlands wastewater treatment for removing pollutants from agricultural drains in order to be reused directly or after mixing with freshwater canals.

\section{WATER QUALITY OF NILE RIVER}

Before the construction of AHD, there were seasonal and monthly changes in the physical and chemical constituents of the water of Nile River. During the flood period (July: October), the concentrations of total dissolved solids (TDS) in the water were at the minimum and those of total suspended solids (TSS), expressed as turbidity, were at the maximum (Table 6). Ball (1939) reported that the amounts of suspended matter deposited in the River, during period 1913-1932 varied according to seasonal variations and were the highest at flood season (Table 7). Within the construction of AHD in 1964, silt deposits on the flood plains decreased from 24 million ton per year to 2.5 million tons per year (Abdel Wahaab, 1995). At the present time, the water released from AHD is practically silt free and presence of suspended particulates in water is the results of biological activities of phytoplankton and algae and of shoreline erosion (El Gamal and Shafik, 1985). As a result, Nile Water salinity increased, during its flow south-north direction, from about 150 $\mathrm{mg} / \mathrm{l}$ at Aswan to about $250 \mathrm{mg} / \mathrm{l}$ near Cairo (El-Gamal and Shafik, 1985; Welsh and Mancy, 1992).

\subsection{Water Quality Of Lake Nasser}

The inflow to Lake Nasser carries salts from the watersheds of the Blue and White Nile and, therefore, exhibits marked seasonal variations in water salinity (Whittington and Guariso, 1983). The White Nile water has higher concentrations of TDS and the flood flow of Blue Nile brings water of lower salt concentration to the southern part of Lake Nasser. Data recorded at Khartoum in the period 1974-1976 can be assumed to characterize the flow entering Lake Nasser (Table 8).

Since the construction of AHD in 1968, the Lake water quality had changed as a result of both entering several factors into the lake and to self assimilation of organic substances caused by human activities such as navigation, fishing,... etc. It seems that most changes in water quality are concerned with slight increases in the levels of TDS, COD, heavy metals and fecal coliform (Table 9).

According to data reported by NRI (2008), the surface water of the lake has $\mathrm{pH}$ values in the range 7.58.3 which are within the permissible limits of the law 48/1982 (7.0-8.5), concentrations of DO ranging between 7.5 and $9.9 \mathrm{mg} / \mathrm{l}$ which exceeded the standard of the law 48/1982 ( $\geq 5 \mathrm{mg} / \mathrm{l})$, concentrations of TDS varying from 124 to $168 \mathrm{mg} / \mathrm{l}$ which comply with the law 48/1982 (500 mg/l). It has been also reported that the values of COD varied, on the average, from 8.0 to $14.0 \mathrm{mg} / \mathrm{l}$, and were higher during high flow (7-24 mg/l) than during low flow $(8-11 \mathrm{mg} / \mathrm{l})$. Thus, the levels of COD at high flow did not comply with the law 48/1982 $(10 \mathrm{mg} / \mathrm{l})$ while opposite was recorded during low flow. In Concern with $\mathrm{BOD}_{5}$ in lake water, the levels were within the standard limits of the law 48/1982 (6 mg/l). On the Other hand, the FC counts recorded high values during high flow (10-1200 MPN/100 ml) and low values 
Table 7. Average amounts (million tons per year) of suspended matter (SM) deposited in Nile River during the period 1913-1932 (Ball, 1939)

\begin{tabular}{cccc}
\hline Month & SM & Month & SM \\
\hline Jan. & 0.36 & July & 0.12 \\
\hline Feb. & 0.11 & Aug. & 12.10 \\
\hline Mar. & 0.07 & Sept. & 25.40 \\
\hline Apr. & 0.05 & Oct. & 13.48 \\
\hline May & 0.04 & Nov. & 4.22 \\
\hline June & 0.04 & Dec & 0.90
\end{tabular}

Table 8. Average values of characteristics of water entering Lake Nasser during the period 1974-1976 (Whittingtan and Guariso, 1983)

\begin{tabular}{cccc}
\hline Month & Salinity $(\mathbf{m g} / \mathbf{l})$ & Month & Salinity $(\mathbf{m g} / \mathbf{l})$ \\
\hline Jan. & 115 & July & 98 \\
\hline Feb. & 128 & Aug. & 105 \\
\hline Mar. & 136 & Sept. & 106 \\
\hline Apr. & 155 & Oct. & 96 \\
\hline May & 165 & Nov. & 93 \\
\hline June & 132 & Dec & 103 \\
\hline
\end{tabular}

Table 9. The quality of surface water of Lake Nasser $(\mathrm{mg} / \mathrm{l})$

\begin{tabular}{cccc}
\hline Constituent & $\begin{array}{c}\text { El-Gamal and Shafik } \\
(\mathbf{1 9 8 5})\end{array}$ & $\begin{array}{c}\text { Saad et al. } \\
(\mathbf{2 0 1 1})\end{array}$ & $\begin{array}{c}\text { Law 48/1982 } \\
(\text { Art 60) }\end{array}$ \\
\hline TDS & 160 & 172 & $<500$ \\
\hline DO & 10.5 & 8.5 & $\geq 5$ \\
\hline pH & 8.2 & - & $7-8.5$ \\
\hline BOD $_{5}$ & 1.3 & 1.5 & $<6$ \\
\hline COD & - & 7.8 & $<10$ \\
\hline
\end{tabular}

during low flow(10-120 MPN/100 ml) which comply with the standard of law 48/1982 and Decree 8/1983 (2500 MPN/100 ml). However, the concentrations of $\mathrm{Cd}, \mathrm{Fe}$, and $\mathrm{Pb}$ in lake water were higher than the standard limits of the law 48/1982 (0.01, 1.0 and 0.05 $\mathrm{mg} / \mathrm{l}$, respectively. Saad et al. (2011) interpreted an integrated water management of Lake Nasser and expected an increase in the concentration of $\mathrm{BOD}_{5}$ from $1.5 \mathrm{mg} / \mathrm{l}$ in the year 2009 to $6.0 \mathrm{mg} / \mathrm{l}$ in the year 2020 which is a value within the standard limit of law 48/1982 (6 mg/l).

\subsection{Water Quality Of Nile Valley}

After the construction of AHD, Nile Water Quality has become primarily dependent upon water quality characteristics of Lake Nasser (Table 9). In addition, the changes in Nile Water quality are found to be also due to a combination of several factors including (i) hydrodynamic regime of the river, regulated by barrages, (ii) agricultural return flows, and (iii) domestic and industrial effluents discharging in the river. Abdel Satar (2005) reported that these changes are more pronounced as the river flows south- north. He also reported that water quality of main stream of the river, from Aswan to Delta Barrage is considered good according to FAO (1992). This indicates high self assimilation capacity of Nile River. Earlier investigation claimed that the level of DO usually recovered as a result of atmospheric reaeration especially in the water of mid stream and increased from $4 \mathrm{mg} / \mathrm{l}$ at Aswan to a range from 9 to $10 \mathrm{mg} / \mathrm{l}$ at $200 \mathrm{~km}$ DS Aswan City (Kelley and Walsh, 1992). Abdel Satar (2005) also found that DO concentration in Nile water increased from $5.56 \mathrm{mg} / \mathrm{l}$ at Edfo City to $10.70 \mathrm{mg} / \mathrm{l}$ at Cairo City. Wahaab and Badawy (2004) recorded levels of DO, in Nile Water at $40 \mathrm{Km}$ DS AHD, varying from 3.1-9.5 $\mathrm{mg} / \mathrm{l}$ with $87 \%$ of the observed values exceeded the standard limit of the law 48/1982 ( $\geq 5 \mathrm{mg} / \mathrm{l})$.

Taking into account the geographical features, administration, boundaries, human activities and the presence of Barrages, built for the purpose of elevating Nile water level to supply irrigation canals, the river between Aswan and Cairo has been conventionally divided into four segments as shown in Fig 1 (El-Gamal and Shafik 1985 and Elsokkary, 1992): (i) segment 1 from zero $\mathrm{km}$ (old Aswan Dam) to $167 \mathrm{Km}$ (Esna Barrage), (ii) segment 2 from $167 \mathrm{~km}$ to $359 \mathrm{~km}$ (Naga Hamadi Barrage), (iii) segment 3 from $359 \mathrm{~km}$ to 544 $\mathrm{km}$ (Assuit Barrage) and (iv) segment 4 from $544 \mathrm{~km}$ to 946 km (Cairo/ Delta Barrage). 
Because organic and inorganic pollutants discharged in Nile River are strongly diluted and degraded, especially within the stream between Aswan and Cairo, water of mid-stream has the average relatively good quality. On the other hand, water of riverbank is much more polluted and considered of lower quality than that of mid-stream water. Because of that, mid-stream water sampling and analysis has been utilized and adopted throughout presentation of this article.

Analytical results of Nile water samples carried out by El-Gamal and Shafik (1985) showed that the levels of DO were within the range 6.45-7.55 mg/l (Table 10). As shown in Table 11 the levels of $\mathrm{BOD}_{5}$ are relatively high especially in waters of segment $1(7.45 \mathrm{mg} / \mathrm{l})$ and of segment $4(6.65 \mathrm{mg} / \mathrm{l})$ while low levels are recorded for segment $2(4.93 \mathrm{mg} / \mathrm{l})$ and segment $3(3.35 \mathrm{mg} / \mathrm{l})$. The levels of TDS and FC were mostly low. On the other hand, samples collected in 2001 (APRP, 2002), the levels of $\mathrm{BOD}_{5}$ and TDS (Table 12) were almost less than the standard limits of Low $48 / 1982\left(6\right.$ BOD $_{5} \mathrm{mg} / \mathrm{l}$ and $500 \mathrm{TDS} \mathrm{mg} / \mathrm{l})$. However, the levels of COD in waters of segment 1 and 4 exceed the limits of the law 48/1982 (10 mg/l). In addition, the counts of FC in water of the four segments were within the consent of Law 48/1982. Decree 8/1983. These data point out that the water of Nile River between Aswan and Cairo is fairly good which indicates high self- assimilation capacity of the Nile River within this area of the stream.
Study on Nile water quality status carried out during 2007 (NRI, 2008) showed that the pH values of Nile water varied from 7.95 to 8.63 during low flow (Feb. 2007) and from 7.64 to 8.25 during high flow (Aug. 2007). This study showed that the concentrations of DO ranged between 7.41 and $9.44 \mathrm{mg} / \mathrm{l}$ during low flow and between 5.42 and $8.2 \mathrm{mg} / \mathrm{l}$ during high flow. These DO levels comply with the standard limits of the law $48 / 1982(\geq 5 \mathrm{mg} / \mathrm{l})$. On the other hand, the levels of COD were higher at low flow $(8.0-27.0 \mathrm{mg} / \mathrm{l})$ than at high flow $(5-18 \mathrm{mg} / \mathrm{l})$, about $72 \%$ of the tested sites had exceeded the standard limits of the law 48/1982 (10 $\mathrm{mg} / \mathrm{l})$. The analytical data also showed that the levels of $\mathrm{BOD}_{5}$ varied from 2.0 to $8.0 \mathrm{mg} / \mathrm{l}$ at low flow and from 1.6 to $13.00 \mathrm{mg} / \mathrm{l}$ at high flow, about of $11 \%$ of the tested site had exceeded the standard limits of the law 48/1982 (6 mg/l). The results of this report (NRI, 2008) showed that the concentrations of TDS of water of Nile Valley were almost less than the standard limit of law 48/1982 (500 mg/l). These levels were almost higher during low flow (150-255 mg/l) than higher flow (169$190 \mathrm{mg} / \mathrm{l})$ and increased towards south-north direction with mean values of $155 \mathrm{mg} / \mathrm{l}$ at Aswan and $215 \mathrm{mg} / \mathrm{l}$ at Cairo. It has been also reported (NRI, 2008) that the concentrations of heavy metals $(\mathrm{Cd}, \mathrm{Cu}, \mathrm{Cr}, \mathrm{Fe}, \mathrm{Mn}, \mathrm{Pb}$ and $\mathrm{Zn}$ ) in Nile water were less than the standard limits of the law $48 / 1982(0.01,1.0,0.05,1.0,0.5,0.05$ and $1.0 \mathrm{mg} / \mathrm{l}$, respectively), except for $\mathrm{Fe}$ in waters of segments 1 and 2, Cr of segment 4, and Mn for segments 2 and 3, which exceeded these standard limits.

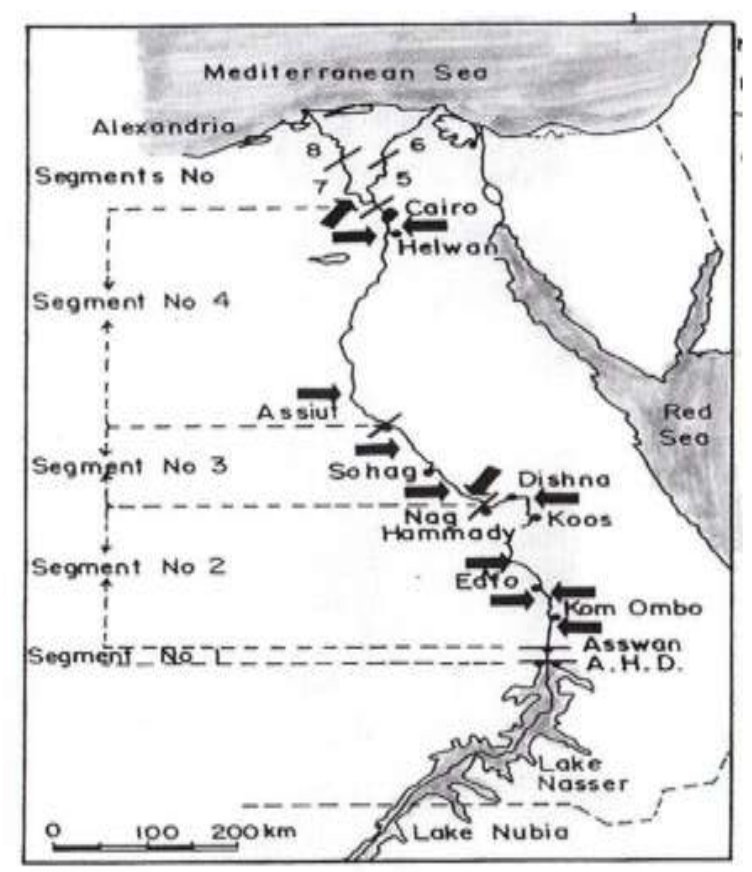

Fig. 1. Map of Egypt showing effluent outfalls and location of segments along the Nile River (Elsokkary, 1992) 
Table 10. Analytical results of the water of Nile River for samples collected in 1984 (EIGamal and Shafik, 1985)

\begin{tabular}{lcccccc}
\hline Name and location & $\begin{array}{c}\text { Distance } \\
\text { from AHD }(\mathbf{k m})\end{array}$ & $\mathbf{p H}$ & $\begin{array}{c}\text { DO } \\
(\mathbf{m g} / \mathbf{l})\end{array}$ & $\begin{array}{c}\mathbf{B O D}_{\mathbf{5}} \\
(\mathbf{m g} / \mathbf{l})\end{array}$ & $\begin{array}{c}\text { TDS } \\
(\mathbf{m g} / \mathbf{l})\end{array}$ & $\begin{array}{c}\text { FC } \\
(\mathbf{M P N} / \mathbf{1 0 0} \mathbf{~ m l})\end{array}$ \\
\hline Lake Nasser Reservoir & -9 & 8.20 & 10.5 & 1.3 & 160 & 7 \\
\hline Aswan & 0 & 8.20 & 9.2 & 3.0 & 160 & 35 \\
\hline Khaur El-Sail & 10.1 & 8.20 & 9.2 & 6.6 & 188 & 45 \\
\hline Kom Ombo & 49.4 & 8.00 & 8.0 & 9.6 & 280 & 900 \\
\hline Menaha & 55.2 & 7.80 & 8.5 & 10.6 & 286 & 140 \\
\hline Hawamdia & 912.0 & 8.30 & 6.9 & 7.2 & 224 & 350 \\
\hline Kotsica & 915.0 & 7.75 & 7.0 & 7.8 & 220 & 250 \\
\hline Kasr El-Nil & 930 & 7.95 & 8.0 & 5.0 & 226 & 250 \\
\hline
\end{tabular}

Table 11. Analytical results of the water of Nile River for samples collected in 1984 from the four segments (El-Gamal and Shafik, 1985)

\begin{tabular}{ccccccc}
\hline Segment No. & $\begin{array}{c}\text { Distance } \\
\text { from AHD }(\mathbf{k m})\end{array}$ & $\mathbf{p H}$ & $\begin{array}{c}\text { DO } \\
(\mathbf{m g} / \mathbf{l})\end{array}$ & $\begin{array}{c}\mathbf{B O D}_{\mathbf{5}} \\
(\mathbf{m g} / \mathbf{l})\end{array}$ & $\begin{array}{c}\text { TDS } \\
(\mathbf{m g} / \mathbf{l})\end{array}$ & $\begin{array}{c}\text { FC } \\
(\mathbf{M P N} / \mathbf{1 0 0} \mathbf{~ m l})\end{array}$ \\
\hline 1 & $0-167$ & 8.30 & 6.85 & 7.45 & 228 & 280 \\
\hline 2 & $167-359$ & 8.20 & 6.45 & 4.93 & 255 & 800 \\
\hline 3 & $359-544$ & 8.16 & 7.55 & 3.35 & 240 & 450 \\
\hline 4 & $544-964$ & 8.00 & 7.30 & 6.65 & 260 & 250 \\
\hline
\end{tabular}

Table 12. Water quality of Nile River for samples collected in 2001 (APRP, 2002)

\begin{tabular}{ccccc} 
Segment No. & $\begin{array}{c}\text { COD } \\
(\mathbf{m g} / \mathbf{l})\end{array}$ & $\begin{array}{c}\mathbf{B O D}_{\mathbf{5}} \\
(\mathbf{m g} / \mathbf{l})\end{array}$ & $\begin{array}{c}\text { TDS } \\
(\mathbf{m g} / \mathbf{l})\end{array}$ & $\begin{array}{c}\text { FC } \\
(\mathbf{M P N} / \mathbf{1 0 0} \mathbf{~ m l})\end{array}$ \\
\hline 1 & 12.6 & 1.28 & 179 & 500 \\
\hline 2 & 9.3 & 1.75 & 190 & 1500 \\
\hline 3 & 10.2 & 2.10 & 203 & 400 \\
\hline 4 & 21.2 & 2.63 & 285 & 700 \\
\hline Law 48/1982 & $<10$ & $<6$ & $<500$ & - \\
\hline Decree 8/1983 & - & - & - & $<2500$ \\
\hline
\end{tabular}

\subsection{Water Quality Of Canals Of Nile Valley}

According to studies carried out APRP (2002) and EPRP (2003), the water quality of the main canals of Nile valley is summarized in Table 13. Higher concentration levels of COD were recorded in waters of Naga Hamadi Canal, Ibrahimia Canal than the standard limits of the law 48/1982 (10 mg/l). There were also higher FC counts of water of Bahr Yusef Canal than the standard limits of the law 48/1982 and Decree 8/1983 (2500 MPN/100ml). On the other hand, the levels of $\mathrm{DO}, \mathrm{BOD}_{5}$ and TDS, in waters of this canal were within the permissible levels of Law 48/1982 ( $\geq 5 \mathrm{mg} / \mathrm{l}, 6 \mathrm{mg} / \mathrm{l}$ and $500 \mathrm{mg} / \mathrm{l}$ ).

Study carried out by NRI (2008) showed $\mathrm{pH}$ values varying from 8.3 to 8.5 in water of Ibrahimia Canal, from 7.5 to 7.8 in Nag Hamadi Canals, and an average of 7.8 in Bahr Yusef Canal. These $\mathrm{pH}$ values were higher during low flow than high flow and were within the standard limit of law 48/1982 (7.0-8.5). This study also showed that the levels of DO varied from 8.5 to 9.5 $\mathrm{mg} / \mathrm{l}$ in water of Naga Hamadi Canal, from 8.6 to 9.5 $\mathrm{mg} / \mathrm{l}$ in water of Ibrahimia Canal and around $6.0 \mathrm{mg} / \mathrm{l}$ in water of Bahr Yusef Canal. Lower levels of DO were recorded during high flow than low flow, and were almost within the permissible limits of law 48/1982 ( $\geq 5$ $\mathrm{mg} / \mathrm{l})$. In addition, the concentration levels of COD varied from 11.0 to $17 \mathrm{mg} / \mathrm{l}$ in water of Naga Hamadi Canal, from 4.0 to $8.0 \mathrm{mg} / \mathrm{l}$ in water of Ibrahimia Canal and from 4.0 to $5.0 \mathrm{mg} / \mathrm{l}$ in water of Bahr Yusef Canal. These levels were almost higher during low flow than high flow. It is clear from these data that water of Naga Hamadi Canal contains higher levels of COD than the permissible limit of law 48/1982 (10 mg/l). With respect to $\mathrm{BOD}_{5}$ levels, the water of Naga Hamadi Canal contained from 1.5 to $3.2 \mathrm{mg} / \mathrm{l}$, of Ibrahimia Canal from 2.0 to $3.0 \mathrm{mg} / \mathrm{l}$ and Bahr Yusef Canal from 1.0 to 4.0 $\mathrm{mg} / \mathrm{l}$. These levels were generally less than the standard limit of law 48/1982 (6 mg/l). As reported by NRI (2008), the concentrations of TDS in the water of the three canals were almost less than the standard limit of the law 48/1982 (500 mg/l) and were almost higher during low flow than during high flow. Fecal coliform counts were the highest in water of Bahr Yusef (6000 MPN/100 ml) and the lowest in water of 
Table 13. Water quality of canals of Nile Valley for samples collected in 2001 (APRP, 2002)

\begin{tabular}{lcccccc}
\hline \multicolumn{1}{c}{ Segment No. } & $\begin{array}{c}\text { Distance } \\
\text { from AHD } \\
(\mathbf{k m})\end{array}$ & $\begin{array}{c}\text { DO } \\
(\mathbf{m g} / \mathbf{l})\end{array}$ & $\begin{array}{c}\text { COD } \\
(\mathbf{m g} / \mathbf{l})\end{array}$ & $\begin{array}{c}\mathbf{B O D}_{\mathbf{5}} \\
(\mathbf{m g} / \mathbf{l})\end{array}$ & $\begin{array}{c}\text { TDS } \\
(\mathbf{m g} / \mathbf{l})\end{array}$ & $\begin{array}{c}\mathbf{F C} \\
(\mathbf{M P N} / \mathbf{1 0 0} \mathbf{~ m l})\end{array}$ \\
\hline West Naga Hamadi & 416 & 7.22 & 18.2 & 4.32 & 200 & 2500 \\
\hline East Naga Hamadi & 424 & 6.31 & 25.3 & 5.78 & 213 & 1750 \\
\hline Ibrahimia Canal at Dariout & 580 & 7.84 & 37.2 & 3.55 & 200 & 2000 \\
\hline Bahr Yusef Lahoun & 860 & 7.08 & 10.0 & 1.89 & 305 & 5000 \\
\hline Law 48/1982 & & $\geq 5$ & $<10$ & $<6$ & $<500$ & - \\
\hline Decree 8/1983 & & - & - & - & - & $<2500$ \\
\hline
\end{tabular}

Ibrahimia Canal at Dairout (45 MPN/100ml) and were $1000 \mathrm{MPN} / 100 \mathrm{ml}$ in water of Naga Hamadi Canal The FC counts were higher during high flow than low flow, and were higher than the standard limit of law 48/1982Decree 8/1983 (2500 MPN/100 ml) especially in water of Bahr Yusef Canal.

\subsection{Water Quality Of Rayahs Of Nile Delta}

Higher concentration levels of COD were recorded in waters of Menoufi, Beheri, Nasery Rayahs (Table 14) than the permissible level of law 48/1982. On the other hand, the concentrations of $\mathrm{BOD}_{5}$ and TDS were within the standard limits of this law. However, the concentrations of DO in water of Beheri and Nasery Rayahs were within the standard limit of Law 48/1982 while that of Menoufi was little fir. Table 14 also showed high counts of FC in waters of Menoufi and Nasery Rayahs than the standard limit of Law 48/1982Decree 8/1983 (2500 MPN/100ml).

Study carried out by NRI (2008) showed that the waters of Menoufi Rayah have $\mathrm{pH}$ values between 6.8 and 8.0, DO values between 5.0 and $8.0 \mathrm{mg} / \mathrm{l}$, BOD values from 1.0 to $6.0 \mathrm{mg} / \mathrm{l}$. Higher values of $\mathrm{pH}$, DO, $\mathrm{COD}$ and $\mathrm{BOD}_{5}$ were recorded during high flow than low flow. The levels of TDS varied from 200 to 250 $\mathrm{mg} / \mathrm{l}$ with higher level during low flow than high flow. The counts of FC in the water of Rayah varied from 2000 to $4000 \mathrm{MPN} / 100 \mathrm{ml}$ with higher values during high flow than low flow. In additions, the concentrations of $\mathrm{Cd}, \mathrm{Cr}, \mathrm{Cu}, \mathrm{Fe}, \mathrm{Mn}, \mathrm{Pb}$ and $\mathrm{Zn}$ in water of Menoufi Rayah were less than the standard limits of Law 48/1982.

Table 14. Water quality of Rayahs of Nile Delta for samples collected in 2001 (APRP, 2002)

\begin{tabular}{lccccc}
\hline Segment & $\begin{array}{c}\text { DO } \\
(\mathbf{m g} / \mathbf{l})\end{array}$ & $\begin{array}{c}\text { COD } \\
(\mathbf{m g} / \mathbf{l})\end{array}$ & $\begin{array}{c}\mathbf{B O D}_{\mathbf{5}} \\
(\mathbf{m g} / \mathbf{l})\end{array}$ & $\begin{array}{c}\text { TDS } \\
(\mathbf{m g} / \mathbf{l})\end{array}$ & $\begin{array}{c}\text { FC } \\
(\mathbf{M P N} / \mathbf{1 0 0} \mathbf{~ m l})\end{array}$ \\
\hline Menoufi Rayah & 5.97 & 16.1 & 3.02 & 225 & 10000 \\
\hline Beheri Rayah & 7.58 & 14.2 & 1.74 & 220 & 1000 \\
\hline Nasery Rayah & 6.71 & 12.3 & 3.96 & 220 & 10000 \\
\hline Law 48/1982 & $\geq 5$ & $<10$ & $<6$ & $<500$ & - \\
\hline Decree 8/1983 & - & - & - & - & $<2500$ \\
\hline
\end{tabular}

\subsection{Water Quality Of Damietta Branch}

The average value of COD in water of Damietta Branch of Nile Delta was higher than the standard value of law 45/1982 (Table 15 and Fig 2). On the other hand, the levels of $\mathrm{BOD}_{5}$ and TDS were within the standard limits of this law. However, FC counts had exceeded the limits of Law 48/1982-Decree 8/1983 (2500 MPN/100 $\mathrm{ml})$.

According to NRI (2008), the $\mathrm{pH}$ values in water of Damietta Branch varied from 7.34 to 7.98, and those of DO varied from $6.3 \mathrm{mg} / \mathrm{l}$ (high flow) to $8.4 \mathrm{mg} / \mathrm{l}$ (low flow). Both values of $\mathrm{pH}$ and $\mathrm{DO}$ are within the standard limits of law 48/1982. On the other hand, the levels of COD were higher during low flow (average of 12.0 $\mathrm{mg} / \mathrm{l}$ ) than high flow (average $10.5 \mathrm{mg} / \mathrm{l}$ ) and, therefore, exceeded the standard limit of law 48/1982 (10mg/l). However, the levels of $\mathrm{BOD}_{5}$ were higher during high flow (average $5.8 \mathrm{mg} / \mathrm{l}$ ) than low flow (Average of 4.0 $\mathrm{mg} / \mathrm{l})$ and within the standard of law 48/1982 (6 mg/l).

According to NRI (2008), the concentrations of TDS were higher during low flow (range of 316-346 mg/l) than high flow (range of $205-271 \mathrm{mg} / \mathrm{l}$ ) which are less than the limit of law 48/1982 (500 mg/l). In addition, FC counts varied from 250 to $10000 \mathrm{MPN} / 100 \mathrm{ml}$ during high flow and from 20 to $2500 \mathrm{MPN} 100 \mathrm{ml}$ during low flow. These values, on the average, exceeded the limit of Law 48/1982- Decree 8/1983 (2500 MPN/100 ml). There were generally low concentration levels of $\mathrm{Cd}, \mathrm{Cr}$, $\mathrm{Cu}, \mathrm{Fe}, \mathrm{Mn}, \mathrm{Pb}$ and $\mathrm{Zn}$ in water of Damietta Branch than the limits of Law 48/1982. 
Table 15. Water quality of Damietta and Rosetta Branches of Nile Delta (APRP, 2002)

\begin{tabular}{lcccc}
\hline \multicolumn{1}{c}{ Segment } & $\begin{array}{l}\text { COD } \\
(\mathbf{m g} / \mathbf{l})\end{array}$ & $\begin{array}{c}\mathbf{B O D}_{\mathbf{5}} \\
(\mathbf{m g} / \mathbf{l})\end{array}$ & $\begin{array}{c}\text { TDS } \\
(\mathbf{m g} / \mathbf{l})\end{array}$ & $\begin{array}{c}\text { FC } \\
(\mathbf{M P N} / \mathbf{1 0 0} \mathbf{~ m l})\end{array}$ \\
\hline Damietta & 15.4 & 2.13 & 320 & 20800 \\
\hline Rosetta & 19.0 & 6.61 & 387 & 500 \\
\hline Law 48/1982 & $<10$ & $<6$ & $<500$ & - \\
\hline Decree 8/1983 & - & - & - & $<2500$ \\
\hline
\end{tabular}

\subsection{Water Quality Of Rosetta Branch}

High levels of COD were recorded in water of Rosetta Branch (Table 15 and Fig. 2). These levels exceeded the standard limit of Law 48/1982. However, the concentrations of $\mathrm{BOD}_{5}$, TDS and FC counts were within the limits of Law 48/1982-Decree 8/1983 (Table 15). According to study carried out by NRI (2008), the $\mathrm{pH}$ values of water of Rosetta Branch varied from 7.64 to 7.94 during high flow and from 7.5 to 7.73 during low flow which comply with law 48/1982. On the other hand, the levels of DO varied 1.8 to $9.5 \mathrm{mg} / \mathrm{l}$ during low flow and from 4.9 to $5.2 \mathrm{mg} / \mathrm{l}$ during high flow. On the average, it seems that DO levels in water of Rosetta Branch are low and did not comply with law 48/1982. In addition, the levels of COD varied from 18 to $24 \mathrm{mg} / \mathrm{l}$ during low flow and from 13 to $14 \mathrm{mg} / \mathrm{l}$ during high flow. These values exceeded the standard limit of Law 48/1982. The values of $\mathrm{BOD}_{5}$ varied from 4.0 to 10.0 $\mathrm{mg} / \mathrm{l}$ during low flow and from 7.0 to $13.5 \mathrm{mg} / \mathrm{l}$ during high flow which indicate high levels of $\mathrm{BOD}_{5}$ in water of Rosetta Branch than the limit of Law 48/1982.
The concentrations of TDS in water of Rosetta Branch varied from 375 to $480 \mathrm{mg} / \mathrm{l}$ during low flow and from 280 to $300 \mathrm{mg} / \mathrm{l}$ during high flow. These levels of TDS comply with the limit of Law 48/1982 (500 $\mathrm{mg} / \mathrm{l})$.

According to NRI (2008), FC counts varied from 320 to $4500 \mathrm{MPN} / 100 \mathrm{ml}$ during low flow and from 50 to $1000 \mathrm{MPN} / 100 \mathrm{ml}$ during high flow. On the average, FC during low flow had exceeded the limit of Law 48/1982- Decree 8/1983 (2500 MPN/100 ml). On the other hand, the concentrations of $\mathrm{Cd}, \mathrm{Cr}, \mathrm{Cu}, \mathrm{Fe}, \mathrm{Mn}, \mathrm{Pb}$ and $\mathrm{Zn}$ were less than the limits of Law 48/1982. These results indicate that the water of Rosetta Branch is highly polluted with organic loads, as indicated by low DO and high COD and $\mathrm{BOD}_{5}$ levels. Several studies reported that the waters of the Branch receive high loads of inorganic and organic pollutants from various outfalls discharging in the Branch (Badr et al., 2006; El-Gamal and El-Shazely, 2008 and El-Bouraie et al., 2010).

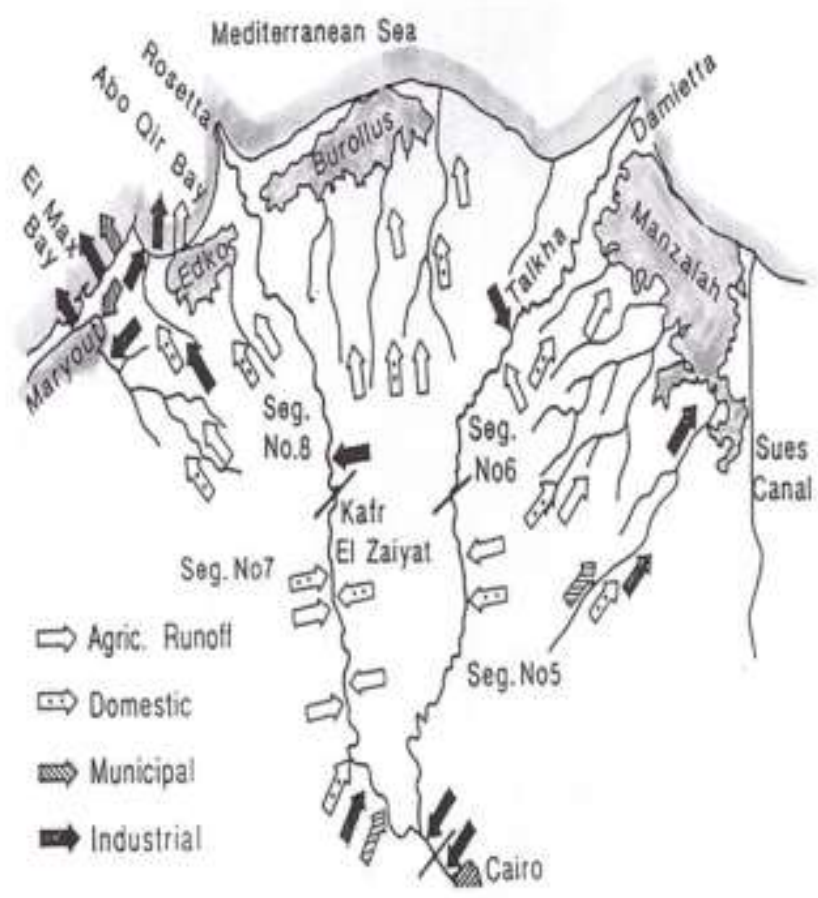

Fig. 2. Map of Delta Barrage showing effluent outfalls and location of segments along the Nile Delta (Elsokkary, 1992) 


\section{AGRICULTURAL DRAINAGE WATER}

Drainage water seeping from agricultural fields is considered non-point sources of pollution. These nonpoint sources are concentrated through collecting drains to from point source of pollution for Nile River, Rayahs and canals. The major pollutants in agricultural drainage water are salts, nutrients ( $\mathrm{N}$ and $\mathrm{P})$, pesticides residues, toxic organic and inorganic chemicals and pathogens (DRI, 1995; APRP, 2002; EWRP, 2003 and Wahaab and Badawy, 2004). The pollution Load in the drain significantly increases with rural population density represented by the number of villages small communities existing in the catchment area.

Practically, domestic and industrial pollution sources are likely to exist as the drain catchment area increases (EWRP, 2003). Most of pollutants in water of agricultural drains, beside agricultural water seeping, under Egyptian conditions are from domestic diffuse sources (90.2), domestic point sources (3.2\%) and industrial sources $(6.6 \%)$. Monitoring study carried out by Khan et al. (2011) on agricultural drains in Egypt, defined the main types of pollution point sources input the drains as agricultural runoff, sewage and industrial effluents (Table 16).

\subsection{Agricultural Drainage Water Of Nile Valley}

Most of the drainage water along the Nile Valley (Upper Egypt) flows back to the River as turn flow. The quantity of this water has been accounted by 2.6 BCM/year (Welsh and Mancy, 1992). This water affected significantly the quality of Nile water where salinity increased from relatively low levels (150-250 $\mathrm{mg} / \mathrm{l})$ at Aswan to relatively high levels $(250-350 \mathrm{mg} / \mathrm{l})$ at Cairo (El-Gamal and Shafik, 1985; Abu Zeid, 1992 and Abdel Satar, 2005).

El-Gamal and Shafik, (1985) reported that the total number of liquid discharges to Nile River Between Aswan and Cairo is 67 of which 22 of industrial effluent and 45 of Agricultural drainage water ( Table 17). Recent study (NWRC, 2000) reported that the Nile River between Aswan and Delta Barrage Receives wastewater discharge from 124 point sources of which 67 are agricultural drains and the rest are industrial effluents.

The quality of waters of the drains has been estimated and showed high concentration levels of TDS, COD and BOD (Table 18 and 19). Taking into account the levels of COD and BOD as measures of organic load, the Nile River between Aswan and Delta Barrage had received, during 1989/1999, about $516.632 \mathrm{Kg}$ COD/day and $157.854 \mathrm{Kg} \mathrm{BOD/day} \mathrm{(APRP,} \mathrm{2002).} \mathrm{The}$ worst water quality was estimated in Khour El-Sail Aswan, El-Berba, Kom Ombo and Atsa Drains (Table 20). The organic load discharged into the Nile River between Aswan and Delta Barrage from these drains is shown in Table 21.

NRI (2008) investigated the quality of 29 drains along Nile River between Aswan and Delta Barrage. The results showed that, on the average, $26 \%$ of the drains had lower DO levels than the standard limit of

Table 16. Types of drains discharging in Nile River of Egypt (Khan et al. 2011)

\begin{tabular}{lcc}
\hline Types of drains & Number of drains & \% of Total \\
\hline Agriculture & 61 & 63 \\
\hline Industry & 17 & 18 \\
\hline Electric Power Station & 7 & 7 \\
\hline Treatment plant & 5 & 5 \\
\hline Agriculture \& Industry & 3 & 3 \\
\hline Agriculture \& Sewage & 2 & 2 \\
\hline Agriculture \& Industry \& Sewage & 2 & 2 \\
\hline Total & 97 & 100 \\
\hline
\end{tabular}

Table 17. Number, types and quantity of discharges into Nile River between Aswan and Delta Barrage (EI-Gamal and Shafik, 1985)

\begin{tabular}{cccccc}
\hline \multirow{2}{*}{ Segment } & \multirow{2}{*}{$\begin{array}{c}\text { Distance } \\
\text { from AHD }(\mathbf{k m})\end{array}$} & \multicolumn{2}{c}{ Number of Discharges } & \multicolumn{2}{c}{ Quantity (mm $\mathbf{3} / \mathbf{y e a r})$} \\
\cline { 3 - 6 } & $0-167$ & Agriculture & Industry & Agriculture & Industry \\
\hline 1 & $167-359$ & 19 & 6 & 300 & 50 \\
\hline 2 & $359-544$ & 11 & 5 & 1150 & 150 \\
\hline 3 & $544-964$ & 8 & 8 & 520 & 12 \\
\hline 4 & & 45 & 22 & 2570 & 312 \\
\hline Total & & & & & \\
\hline
\end{tabular}


Table 18. Characteristics of liquid discharges to Nile River from Aswan to Delta Barrage for samples collected in 1984 (El-Gamal and Shafik, 1985)

\begin{tabular}{cccc}
\hline Segment & TDS & DO & FC \\
& $(\mathbf{m g} / \mathbf{l})$ & 6.1 & $\begin{array}{c}\text { (mg/l) } \\
(\mathbf{M P N} / \mathbf{1 0 0} \mathbf{~ m l})\end{array}$ \\
\hline 1 & 666 & 4.4 & 1700 \\
\hline 2 & 600 & 3.2 & 1800 \\
\hline 3 & 675 & 3.9 & 1500 \\
\hline 4 & 1975 & 1000 \\
\hline
\end{tabular}

Table 19. Water quality of agriculture drains before discharge into Nile River between Aswan and Delta Barrage (APRP, 2002)

\begin{tabular}{ccccccc}
\hline Segment & $\begin{array}{c}\text { Distance } \\
\text { from AHD }(\mathbf{k m})\end{array}$ & $\begin{array}{c}\text { TDS } \\
(\mathbf{m g} / \mathbf{l})\end{array}$ & $\begin{array}{c}\text { DO } \\
(\mathbf{m g} / \mathbf{l})\end{array}$ & $\begin{array}{c}\text { COD } \\
(\mathbf{m g} / \mathbf{l})\end{array}$ & $\begin{array}{c}\mathbf{B O D}_{\mathbf{5}} \\
(\mathbf{m g} / \mathbf{l})\end{array}$ & $\begin{array}{c}\text { FC } \\
(\mathbf{M P N} / \mathbf{1 0 0} \mathbf{~ m l})\end{array}$ \\
\hline 1 & $0-167$ & 588 & 6.94 & 29.6 & 8.32 & 5000 \\
\hline 2 & $167-359$ & 730 & 9.12 & 45.6 & 5.42 & 2500 \\
\hline 3 & $359-544$ & 458 & 7.67 & 11.3 & 2.48 & 1100 \\
\hline Law 48/1982 Art 65 & $544-964$ & 650 & 5.00 & 31.8 & 10.55 & 6000 \\
\hline
\end{tabular}

Table 20. Water analysis of the most polluted drains point sources at Nile Valley (APRP, 2002)

\begin{tabular}{ccccccc}
\hline Name of Drain & $\begin{array}{c}\text { Distance } \\
\text { from AHD (km) }\end{array}$ & TDS (mg/l) & COD (mg/l) & BOD $_{\mathbf{5}}(\mathbf{m g} / \mathbf{l})$ & $\begin{array}{c}\text { DO } \\
(\mathbf{m g} / \mathbf{l})\end{array}$ & $\begin{array}{c}\text { FC } \\
(\mathbf{M P N} / \mathbf{1 0 0} \mathbf{~ m l})\end{array}$ \\
\hline Khour El-Sail Aswan & 9.9 & 1190 & 102 & 32.8 & 1.91 & 33000 \\
\hline El-berba & 49.1 & 414 & 113 & 42.7 & 3.85 & 22000 \\
\hline Kom Ombo & 51.0 & 325 & 152 & 41.5 & 2.25 & 25000 \\
\hline Asta & 701.2 & 575 & 100 & 38.0 & 1.38 & 35000 \\
\hline Law 48/1982 (Art 65) & & $<500$ & $\geq 5$ & $<15$ & $<10$ & $<5000$ \\
\hline
\end{tabular}

Table 21. Load of organic pollutants discharged into the Nile River between Aswan and Delta Barrage during 2001 (APRP, 2002)

\begin{tabular}{|c|c|c|c|c|c|c|}
\hline \multirow[b]{2}{*}{ Name of Drain } & \multirow{2}{*}{$\begin{array}{l}\text { Distance } \\
\text { from AHD } \\
(\mathbf{k m})\end{array}$} & \multirow{2}{*}{$\begin{array}{l}\text { Discharge } \\
\left(\mathrm{mm}^{3} / \text { day }\right)\end{array}$} & \multicolumn{2}{|c|}{ COD } & \multicolumn{2}{|c|}{ BOD } \\
\hline & & & Kg/day & $\%$ of Tot. & Kg/day & $\%$ of Tot. \\
\hline Khour El-sail Aswan & 9.9 & 0.1 & 10.08 & 1.98 & 3.24 & 2.05 \\
\hline El-berba & 49.1 & 0.15 & 172.67 & 33.33 & 65.25 & 41.29 \\
\hline Kom Ombo & 51.0 & 0.14 & 218.10 & 42.25 & 59.70 & 37.78 \\
\hline Asta & 701.2 & 0.57 & 56.80 & 11.05 & 21.58 & 13.66 \\
\hline
\end{tabular}

Law 48/1982 (not less than $5 \mathrm{mg} / \mathrm{l}$ ), $45 \%$ of drains had higher levels of COD than the limit of Law 48/1982 (15 $\mathrm{mg} / \mathrm{l}), 12 \%$ of drains had higher levels of $\mathrm{BOD}_{5}$ than the limit of law $48 / 1982(10 \mathrm{mg} / \mathrm{l}), 59 \%$ of the drains had higher levels of TDS than the limit of Law 48/1982 (500 $\mathrm{mg} / \mathrm{l}$ ), and $40 \%$ of the drains had higher FC counts than the standard limit of the law 48/1982-Decree 8/1983 (5000 MPN/100ml).

\subsection{Agricultural Drainage Water Of El-Fayoum}

El-Batts Drain at El-Fayoum Governorate is considered the main drain in the region. It receives about $22396 \mathrm{~m}^{3} /$ day effluent from domestic point source, $26213 \mathrm{~m}^{3} /$ day from domestic diffuse sources, and $1468341 \mathrm{~m}^{3} /$ day from agricultural diffuse sources
(Farag and Donia, 2006). The average concentrations of $\mathrm{BOD}_{5}$ in the effluents were $36.7 \mathrm{mg} / /$ in domestic point source, and $92.5 \mathrm{mg} / \mathrm{l}$ in domestic diffuse sources. The average concentrations of TDS were 1100 and 1360 $\mathrm{mg} / \mathrm{l}$ in effluents of these two sources, respectively (Farag and Donia, 2006). In addition, El-Batts Drain receives wastewater from two $\mathrm{WWTP}_{\mathrm{S}}$, two drains and one pump station (Table 22). It discharges its water in Lake Qaroun, and therefore is considered the main source of Pollutants into the lake. However, according to Law 48/1982 (Art. 66), the quality of wastewater effluents from WWTPs and from pump station comply with this law, while those of the two drains: El-Edwa and El-Roda do not comply with this law (Table 22). 
Table 22. Quality and quantity of wastewater discharging in El-Batts drain at El-Fayoum (Farag and Donia, 2006)

\begin{tabular}{lccc}
\hline Sources & Discharge $\mathbf{~ m}^{\mathbf{3}} / \mathbf{S e c}$ & BOD $_{\mathbf{5}} \mathbf{( m g / l )}$ & TDS $\mathbf{( m g / \mathbf { l } )}$ \\
\hline WWTP, Old Fayoum & 0.260 & 45.0 & 1240 \\
\hline WWTP, New Fayoum & 0.460 & 25.0 & 1020 \\
\hline El-Edwa & 0.011 & 75.0 & 1360 \\
\hline El-Roda & 0.020 & 110.0 & 1360 \\
\hline Reuse pump station & 0.850 & 40.3 & 1050 \\
\hline Law 48/1982 (Art. 66) & & $<60$ & $<2000$ \\
\hline
\end{tabular}

\subsection{Agricultural Drainage Water Of Nile Delta}

Drains of Nile Delta receive about 13.6 BCM/year of wastewater of which $90 \%$ is agricultural diffuse sources, 6.2 is domestic point sources, $3.5 \%$ is domestic diffuse sources, and $0.5 \%$ is industrial point sources (DRI, 2000). The total organic loads discharging into the main drains; Bahr El-Baker, El-Gharbia and Edko; from domestic and industrial sources have the estimated as follow: 1216097, 570264, and $157753 \mathrm{Kg} /$ day into the three drains, respectively. The main constituents in waters of these drains are shown in Table 23. In terms of "organic loads" as expressed by $\mathrm{COD}$ and $\mathrm{BOD}_{5}$ values; Bahr El-Baker Drain receives $775635 \mathrm{~kg} \mathrm{COD/day} \mathrm{and}$ $440462 \mathrm{~kg}$ BOD/day, El-Garbia Drain receives 34772 $\mathrm{kg} \mathrm{COD/day} \mathrm{and} 222492 \mathrm{~kg} \mathrm{BOD/day}$ and Edko Drain receives $35491 \mathrm{~kg} \mathrm{COD} /$ day and $27075 \mathrm{~kg} \mathrm{BOD} /$ day. (APRP, 2002; and EWRP, 2003).

The salinity of drainage water of Nile Delta, generally, increased as a result of both domestic and industrial pollution and intensive agriculture. It increased from $2000 \mathrm{mg} / \mathrm{l}$ in 1984 to $3000 \mathrm{mg} / \mathrm{l}$ in 1990 and to $2260 \mathrm{mg} / \mathrm{l}$ in $1992 / 1993$, and it is expected to increase, in the near future, to critical levels (Wahaab and Badawy, 2004). Water salinity of the drains at the southern part of Nile Delta varied from 750 to 1000 $\mathrm{mg} / \mathrm{l}$, at the middle part from 1000 to $2000 \mathrm{mg} / \mathrm{l}$, and the northern part from 3500 to $6000 \mathrm{mg} / \mathrm{l}$ (APRP, 2002).

Of significant pollution source to Rosetta Branch is El-Rahawy Drain. This drain receives about 400,000 $\mathrm{m}^{3} /$ day partially treated wastewater from Abu Rawash wastewater treatment plant (WWTP), besides 600,000 $\mathrm{m}^{3} /$ day untreated wastewater from the same plant. It receives also $340,000 \mathrm{~m}^{3} /$ day secondary treated wastewater from Zeinin WWTP. The main source of this water is El-Moheet Drain. The water of El-Rahawy Drain outlet has an average $\mathrm{pH}$ of 6.5 , undetected DO, COD of $67.0 \mathrm{mg} / \mathrm{l}, \mathrm{BOD}_{5}$ of $44.0 \mathrm{mg} / \mathrm{l}$ and TDS of 848 $\mathrm{mg} / \mathrm{l}$ (Badr et al., 2006). It has been reported that the waters of the main drains which are discharging in Rosetta Branch including El-Rahawy, Sabal, Tala, North Tahreer, Zawiet El-Bahr and the three drains of Kafr ElZayat are of low quality (Badr et al., 2006; El-Gamal and Shazely Elewa, 2010; and El-Bouraie at al., 2010) and according to Law 48/1982 (Art. 65) are prohibited to be discharged into the branch. Each of these drains has a certain catchment covering heavily populated area with no wastewater treatment heavily facilities.

Other drains of most significant at west of Nile Delta are Edko, Abu Keer and El-Umoum. These drains receive high loads of pollutants from severl sources (Table 24).

The water of Edko Drain is of low quality (Table 25), and did not comply with Law 48/1982 (Art. 65). However, this drain supplies El-Mahmoudia Canal with water from an outlet near Khairy Drain, in order to cover the need of irrigation along the canal and need of drinking water to Alexandria City. It is clear from Table 25 that the quality of the water of EDKO Drain is low and is changing along its flow south- north direction, where levels of TDS, COD, BOD and FC counts are increased. Edko Drain catchment area covers a highly populated area in which the quality of water in the drain system (main drain and its branches) is deteriorating due to legal and illegal pumping of domestic wastewater (APRP, 2002). The drain, therefore, receives about $30678 \mathrm{Kg}$ COD/day, $27075 \mathrm{Kg}$ BOD/day, 35491Kg SS/day and $64906 \mathrm{Kg}$ TDS/day. Most of the organic load received by the drain is from domestic diffuse sources $(90.2 \%)$, domestic point sources $(3.2 \%)$, and industrial sources $(6.7 \%)$.

El-Umoum Drain is one of the largest drains at west Nile Delta. It receive about $5270099 \mathrm{~m}^{3} /$ day wastewater of which $2500 \mathrm{~m}^{3} /$ day from domestic point sources, $81890 \mathrm{~m}^{3} /$ day from domestic diffuse sources and $5163209 \mathrm{~m}^{3} /$ day from agricultural diffuse sources (APRP, 2002 and EWRP, 2003). The waters discharged from Abu Hommos, Shrishra, Truga, El-Deshoudy and El-Haris are the main supplies of El-Umoum Drain. The catchment of the drain covers highly populated area with villages and small communities lacking wastewater treatment facilities, and this indicates that the drain usually receives highly polluted wastewater. As a result and according to the data given in Table 26, the water of El-Umoum Drain had a wide range for each character. According to study carried out by DRI (2000) the pH of 
Table 23. Average value of main characteristics of the water of main drains of Nile Delta (APRP, 2002)

\begin{tabular}{lccc}
\hline Name of Drain & $\begin{array}{c}\text { COD } \\
(\mathbf{m g} / \mathbf{l})\end{array}$ & $\begin{array}{c}\mathbf{B O D}_{\mathbf{5}} \\
(\mathbf{m g} / \mathbf{l})\end{array}$ & $\begin{array}{c}\text { FC } \\
(\mathbf{M P N} / \mathbf{1 0 0 m l})\end{array}$ \\
\hline Bahr El Baqer & 132 & 162 & 40000 \\
\hline El Gharbia & 128 & 84 & 40000 \\
\hline Edko & 80 & 32 & 20000 \\
\hline Law 48/1982 Art 65 & $<15$ & $<10$ & $<5000$ \\
\hline
\end{tabular}

Table 24. Quantity of effluents $\left(\mathrm{m}^{3} / \mathrm{day}\right)$ discharged to drains of west Nile Delta (APRP, 2002)

\begin{tabular}{lcccc}
\hline Name of Drain & $\begin{array}{c}\text { Domestic } \\
\text { point sources }\end{array}$ & $\begin{array}{c}\text { Domestic } \\
\text { Diffuse sources }\end{array}$ & $\begin{array}{c}\text { Industrial } \\
\text { point sources }\end{array}$ & $\begin{array}{c}\text { Agricultural } \\
\text { point sources }\end{array}$ \\
\hline Edko & 20000 & 57346 & 7470 & 4232034 \\
\hline El-Umoum & 25000 & 81890 & - & 5163209 \\
\hline Abu keer & - & 15803 & 22897 & 621592 \\
\hline
\end{tabular}

Table 25. Water analysis of Edko Drain

\begin{tabular}{|c|c|c|c|c|c|c|c|c|c|}
\hline \multirow[b]{2}{*}{ Location } & \multirow[b]{2}{*}{ Month } & \multicolumn{4}{|c|}{2001} & \multicolumn{4}{|c|}{2009} \\
\hline & & $\begin{array}{c}\text { TDS } \\
(\mathrm{mg} / \mathrm{l})\end{array}$ & $\begin{array}{l}\text { COD } \\
(\mathrm{mg} / \mathrm{l})\end{array}$ & $\begin{array}{l}\mathrm{BOD}_{5} \\
(\mathrm{mg} / \mathrm{l})\end{array}$ & $\begin{array}{c}\text { FC } \\
(\text { MPN/100 ml) }\end{array}$ & $\begin{array}{l}\text { TDS } \\
(\mathrm{mg} / \mathrm{l})\end{array}$ & $\begin{array}{l}\text { COD } \\
(\mathrm{mg} / \mathrm{l})\end{array}$ & $\begin{array}{l}\text { BOD }_{5} \\
(\mathrm{mg} / \mathrm{l})\end{array}$ & $\begin{array}{c}\text { FC } \\
(\mathrm{MPN} / 100 \mathrm{ml})\end{array}$ \\
\hline \multirow{2}{*}{$\begin{array}{l}\text { US Khairy } \\
\text { Drain }\end{array}$} & Feb. & 486 & 32 & 21 & 16900 & 760 & 30 & 7 & 9000 \\
\hline & Aug & 716 & 37 & 23 & 65000 & 738 & 35 & 7 & 9000 \\
\hline \multirow{2}{*}{$\begin{array}{l}\text { DS Khairy } \\
\text { Drain }\end{array}$} & Feb. & 683 & 40 & 31 & 29700 & 881 & 33 & 8 & 24000 \\
\hline & Aug & 643 & 91 & 52 & 20300 & 768 & 29 & 9 & 60000 \\
\hline \multirow{2}{*}{$\begin{array}{l}\text { US Edko } \\
\text { irrigation PS. }\end{array}$} & Feb. & 1218 & 41 & 32 & 3200 & 1025 & 48 & 12 & 60000 \\
\hline & Aug & 1224 & 124 & 73 & 54800 & 938 & 33 & 8 & 240000 \\
\hline
\end{tabular}

Table 26. The main characteristics of the water of the drains of El-Umoum catchment area (Elsokkary and Abukila, 2011)

\begin{tabular}{|c|c|c|c|c|c|c|c|c|c|c|c|c|}
\hline \multirow{2}{*}{ Name of Drain } & \multicolumn{3}{|c|}{ TDS (mg/l) } & \multicolumn{3}{|c|}{ COD (mg/l) } & \multicolumn{3}{|c|}{ BOD $_{5}(\mathrm{mg} / \mathrm{l})$} & \multicolumn{3}{|c|}{ FC (MPN/100 ml) } \\
\hline & 1989 & 2000 & 2010 & 1989 & 2000 & 2010 & 1989 & 2000 & 2010 & 1989 & 2000 & 2010 \\
\hline Abu Hommos & 1350 & 1450 & 1300 & 55 & 74 & 15 & 23 & 32 & 8 & 50000 & 20000 & 35000 \\
\hline Shrishra & 1400 & 1480 & 1550 & 40 & 45 & 12 & 18 & 22 & 6 & 10000 & 28000 & 25000 \\
\hline Trouga & 1650 & 2000 & 2500 & 36 & 30 & 28 & 20 & 22 & 20 & 20000 & 30000 & 35000 \\
\hline El-Deshoudy & 3100 & 3500 & 3300 & 52 & 58 & 48 & 24 & 26 & 13 & 30000 & 28000 & 25000 \\
\hline El-Haris & 2400 & 3500 & 4100 & 35 & 38 & 32 & 14 & 18 & 9 & 25000 & 18000 & 70000 \\
\hline Bab El-Abeed & 4200 & 4300 & 4500 & 36 & 34 & 30 & 12 & 15 & 12 & 35000 & 40000 & 50000 \\
\hline Mean & 2400 & 2700 & 2875 & 42 & 47 & 28 & 19 & 23 & 11 & 28300 & 27300 & 34100 \\
\hline Law 48/1982 Art 65 & & $<500$ & & & $<15$ & & & $<10$ & & & $<5000$ & \\
\hline
\end{tabular}

the water varied from 7.00 to 7.93 , the concentrations of $\mathrm{BOD}_{5}$ varied from 21.0 to $180.0 \mathrm{mg} / \mathrm{l}$, the DO from 2.2 to $7.9 \mathrm{mg} / \mathrm{l}$ and TDS from 4500 to $8500 \mathrm{mg} / \mathrm{l}$. These values do not comply with Law 48/1985. Study carried out by Nagy and Salem (2003) reported concentration levels of BOD in the range from 46 to $93 \mathrm{mg} / \mathrm{l}$, of DO from 4.06 to $7.99 \mathrm{mg} / \mathrm{l}$ and TDS from 1463 to 7167 mg/l. Recently, Elsokkary and Abukila (2011) reported that the concentrations of TDS, COD, $\mathrm{BOD}_{5}$ and $\mathrm{FC}$ counts, of the water of El-Umoum Drain were increasing progressively towards south-north the catchment area
(Table 26). It is clear from these data that the concentration levels of TDS and FC counts have been increased during the last twenty years while the levels of $\mathrm{COD}$ and $\mathrm{BOD}_{5}$ has slightly improved but still do not comply with the limits of Law 48/1982.

\section{NON-CONVENTIONAL WASTEWATER TREATMENT}

Prohibitions of pollution point source from disposing their pollutants in freshwater bodies together with application of efficient technique of wastewater treatment are considered acceptable remediation of the 
disposed water. Of the most significant pollutants, in wastewater are in general; suspended solids, biodegradable organics, pathogens, nutrients, heavy metals and inorganic salts (Trattner and Woods, 1989).

According to several reports (APRP, 2002 and EWRP, 2003), the drainage water of Egypt is a combination of agricultural drainage water, domestic and industrial effluents. This attributed mainly to that most of rural villages in the country do not possess wastewater treatment facility because it is costly and cannot be designed for small and more dispersed rural settlements. Because of that, several treatment alternatives that vary in efficiency and cost should be considered in order to be used under Egyptian conditions. Non-conventional wastewater facility systems can provide realistic solution of the problem. Of these non-conventional facilities is construction instream wetlands system. Within the last 30 years, this system is being a growing practice to mitigate the impact of point and non-point sources of water pollution. The system requires relatively low cost and easy maintenance, and has acceptable removal efficiency for $\mathrm{COD}, \mathrm{BOD}_{5}$, inorganic chemicals and pathogens (Hammer, 1990 and 1997); Mitsch, 1993; Wetzel, 1993; and Zindan et al., 2005). The expected performance of the constructed in-stream wetland system, in general, is shown in Table 27.

Design types and composition of constructed wetlands vary considerably depending on the system design, objective of treatment, wastewater application, geographic climatic location and designer's experience (Hammer, 1997). The following paragraphs represent some examples of constructed in-stream wetland systems.

Gravel bed hydroponic (GBH) wetland system of $100 \mathrm{~m}$ length was used by Stott et al. (1999) for wastewater treatment. They found that the majority of parasite eggs of Ascaris sp., Toxocara sp., and Hymenolepis sp. were significantly removed within the first $25 \mathrm{~m}$ of the GBH wetland system. No eggs were detected in the final effluent from an influent containing 500 eggs/l.

Constructed wetland system established and operated during 1998-2005, at Suez Canal University, Ismailia, Egypt, showed moderate efficiency to remove the load of pathogenic bacteria from the influent. The removal efficiency of that system was $48 \%$ of Salmonell sp., $52 \%$ of Shigella sp., $49 \%$ of Vibro sp., and $49 \%$ of Pseudomn sp. (Abdulla et al., 2007).

Free water surface wetland system employed to treat wastewater showed removal efficiency of $79 \%$ of total
N, 95.4\% pathogens and 10\% of TSS (Abdel Ghaffar and El-Saadi, 2007).

In 2001, Lake Manzala Engineering Wetland Project was designed at south west of Port Said City (GEF, 2005). The project is a cooperative effort among the Global Environmental Facility (GEF), Egyptian Environmental Affair Agency (EEAA) and the United Nation Development Program (UNDP). The wetlands were designed to treat $250000 \mathrm{~m}^{3} /$ day of water from Bahr El-Baqer Drain. The analytical results from the collected data during the period 2003-2004 (Table 28) and during Aug. 2006 (Table 29) indicated significant removal efficiency of the system for the major pollutants (GEF/UNDP, 2009). It has been proved that the Lake Manzala Engineered Wetland Project is characterized by low cost, approximately quarter of the cost of conventional wastewater treatment system. In addition, the field data reported by Zidan et al. (2005) Showed high removal efficiency of the constructed wetland at Manzala project (Table 30).

Another study carried out by Masi et al. (2010) used multistage constructed wetland system consisting of horizontal and vertical subsurface flow for wastewater treatment. revealed acceptable removal efficiency of the system, where the percent removal from COD, nitrification and total coliform were between 66 and 80, 92 and 99, and 98, respectively.

The constructed in-stream wetland system for wastewater treatment has more than an advantage; it is capable of providing high-level treatment and discharges relatively clean water, inexpensive to build, largely selfmaintaining, requiring little or no operation and maintenance time or expense, manageable by operators with very limited training, and capable of providing aesthetic/ recreational / educational benefits (Hammer, 1997). It is clear, therefore, that community and stakeholders cooperation are important issues for both sustainable operation and maintenance. Although instream wetland treatment systems provide several hydrologic advantages at downstream, the potential for negative impact at upstream exist (Mitsch and Gosselink, 2000).

Under Egyptian conditions, the performance of instream wetland treatment system is expected to be equivalent to the primary, and to a certain level, to the secondary conventional treatment of wastewater. In order to minimize the failure risk of the system, three elements should be considered: (i) dredging management of sediments and plants, (ii) vegetation control, and (iii) public acceptance. 
Table 27. The expected performance of wetlands system (Mitsch, 1993)

\begin{tabular}{lccc}
\hline \multicolumn{1}{c}{ Constituent } & Inflow & Outflow & Removal, \% \\
\hline TSS, $\mathrm{mg} / \mathrm{l}$ & 130 & 21 & 84 \\
\hline $\mathrm{BOD}_{5}, \mathrm{mg} / \mathrm{l}$ & 40 & 17 & 58 \\
\hline $\mathrm{COD}, \mathrm{mg} / \mathrm{l}$ & 200 & 92 & 54 \\
\hline Total $\mathrm{P}, \mathrm{mg} / \mathrm{l}$ & 5 & 2.5 & 50 \\
\hline Total $\mathrm{N}, \mathrm{mg} / \mathrm{l}$ & 12 & 5 & 58 \\
\hline $\mathrm{NH}_{4}-\mathrm{N}, \mathrm{mg} / \mathrm{l}$ & 10 & 5 & 50 \\
\hline FC, MPN/100ml & 300000 & 30000 & 90 \\
\hline
\end{tabular}

Table 28. The Removal efficiency (\%) of Lake Manzala Engineered wetland for samples collected during 2003-2004 (GEF, 1993)

\begin{tabular}{lccc}
\hline Constituent & Removal efficiency $(\%)$ & Constituent & Removal efficiency (\%) \\
\hline BOD $_{5}, \mathrm{mg} / \mathrm{l}$ & 70 & Total N, mg/l & 50 \\
\hline TSS, $\mathrm{mg} / \mathrm{l}$ & 80 & TC, MPN/100ml & 98 \\
\hline Total P, mg/l & 50 & FC, MPN/100ml & 98 \\
\hline
\end{tabular}

Table 29. The Removal efficiency (\%) of GEF/UNDP Lake Manzala Engineered wetland for samples collected since Aug. 2006 (GEF/ UNDP, 2009)

\begin{tabular}{lccc}
\hline \multicolumn{1}{c}{ Constituent } & Removal efficiency (\%) & Constituent & Removal efficiency (\%) \\
\hline $\mathrm{BOD}_{5}, \mathrm{mg} / \mathrm{l}$ & 61.2 & Total N, mg/l & 51.4 \\
\hline TSS, $\mathrm{mg} / \mathrm{l}$ & 80.0 & TC, MPN/100ml & 25.9 \\
\hline Total P, $\mathrm{mg} / \mathrm{l}$ & 15.0 & FC, MPN/100ml & 99.7 \\
\hline
\end{tabular}

Table 30. The Removal efficiency (\%) of three cells wetland at Manzala project (Zidan et al., 2005)

\begin{tabular}{lcccc}
\hline \multicolumn{1}{c}{ Constituent } & Cell 1 & Cell 2 & Cell 3 & Average \\
\hline BOD $_{5}, \mathrm{mg} / \mathrm{l}$ & 72 & 72 & 69 & 71 \\
\hline TSS, $\mathrm{mg} / \mathrm{l}$ & 63 & 63 & 63 & 63 \\
\hline Total $\mathrm{N}, \mathrm{mg} / \mathrm{l}$ & 41 & 44 & 42 & 42 \\
\hline Total P, $\mathrm{mg} / \mathrm{l}$ & 41 & 44 & 42 & 42 \\
\hline TC, $\mathrm{MPN} / 100 \mathrm{ml}$ & 98 & 98 & 98 & 98 \\
\hline Fe, $\mathrm{mg} / \mathrm{l}$ & 53 & 58 & 43 & 51 \\
\hline
\end{tabular}

\section{6- CONCLUSION AND RECOMMENDATIONS}

Increasing population and limited annual budget of Nile water (55.5BCM) in Egypt, according to 1959 Nile agreement between Egypt and Sudan, will pose exceeding demand on water in the near future. Because agriculture sector usually use about $84 \%$ of this budget, management of irrigation water must be integrated with other water management projects. The major challenge facing Egypt, therefore, is the urgent need to develop and manage this water budget. Another challenge affecting better water management is the deterioration of Nile water quality as a result of pollution. This is because the main stem of Nile River and the coordinated canals receive continuously enormous amounts of biological and chemical pollutants. However, it has been reported that before construction of AHD, selfassimilation of water Nile River within the stream between Aswan and Delta Barrage, was possible within the annual flood period.
Assessment of ambient water quality statues of the main stem of Nile River between Aswan and Delta Barrage did not exhibit high pollution levels. In this concern the water quality had complied with Law 48/1982 and Decree 8/1983, where the concentration levels of TDS, DO, $\mathrm{BOD}_{5}$, and FC were less than 500, $\geq 5$, and less than $6 \mathrm{mg} / \mathrm{l}$ and $2500 \mathrm{MPN} / 100 \mathrm{ml}$, respectively. However, the levels of COD in the water, especially in the vicinity of big cities and industries along the river, had exceeded the standard limit of Law 48/1982 (10 mg/l). These high levels of COD were combined with reduced levels of DO (Less than $5 \mathrm{mg} / \mathrm{l}$ ) which did not comply with this law. Because of atmospheric reaeration, in Nile water, the levels of DO increased to $9-110 \mathrm{mg} / \mathrm{l}$, south-north direction of Nile flow. Monitoring study revealed that there are four hot pollution point sources discharge their effluent into Nile River. These are Khour El-Sail Aswan, El-Berba, Kom Ombo and Asta Drains. 
Damietta and Rosetta Branches of Nile Delta receive effluents discharged from several pollution sources. The major sources of pollution to Damietta Branch are agricultural drainage water and effluent of Talkha Fertilizer Factory. On the average, the levels of DO in the water of Damette Branch varied from 6.2 to 7.8 $\mathrm{mg} / \mathrm{l}$, of $\mathrm{BOD}_{5}$ from 1.73 to $2.64 \mathrm{mg} / \mathrm{l}$, and of TDS from 235 to $372 \mathrm{mg} / \mathrm{l}$, which comply with Law 48/1982. On the other hand, the levels of COD and FC exceeded the standard limits of Law 48/1982 and Decree 8/1983 (10 $\mathrm{mg} / \mathrm{l}$ and $2500 \mathrm{MPN} / 100 \mathrm{ml}$ ).

The major sources of pollution to Rosetta Branch are El-Rahawy, Sabla, El-Tahreer, Zawiet El-Bahr and Tala Drains beside the industrial effluents at Kafr El-Zayat City. On the average, the concentration levels of COD, BOD, and FC were extremely high and did not comply with Law 48/1982 and Decree 8/1983. However, the levels of TDS and DO were complying with this Law. Estimates of water quality of the two branches of Nile Delta proved that the water of Rosetta Branch is more polluted than that of Damietta Branch.

The agricultural drains of Nile Valley between Aswan and Delta Barrage are significant sources of pollution. Studying the physicochemical characteristics and $\mathrm{FC}$ counts of the major 42 drains discharging into Nile River, it was found that only 10 drains comply with the standards of Law 48/1982 (Art. 65) and Decree $8 / 1983$, and the water quality of other 32 drains exceeded the consent standard of this law. In terms of organic load, Kom Ombo and El-berba Drains contribute by $76 \%$ of the total organic load, calculated as COD, discharged into Nile River from Aswan to Delta Barrage.

The agricultural drains in Nile Delta are characterized by high concentrations of organic and inorganic pollutants. The worst water quality is that of Bahr El-Baqar, El-Gharbia, Edko and El-Umoum Drains. The sources of effluents discharged into these drains are domestic point sources $(6.2 \%)$, industrial point sources $(0.5 \%)$, domestic diffuse sources $(3.5 \%)$, and agricultural diffuse sources (89.7). Within the catchment area, the waters of small drains are considered the supply to the main drains. These small drains receive mostly non-treated wastewater and effluents, in addition to agriculture seeping, from villages and small rural communities. This points out that the water quality of the small drains, within the catchment area, is considered effective source of water quality of the main drain. In order to improve water quality of the main drain, treatment of the water of the small drain should be carried out at the point source of pollution before entering the main collecting drain. Construction of "conventional" wastewater treatment plant (WWTP) is not practical and not economic solution of the problem because of the big numbers of villages and small settlements in the catchment area which are inneed to wastewater treatment facility. Because of that, "non-conventional" wastewater treatment systems can be used as alternatives. Of these systems is the in-stream treatment wetland. The advantages of this system can be summarized as follows (i) high removal efficiency of pollutants especially biological load (BOD), nutrients ( $\mathrm{N}$ and $\mathrm{P}$ ), and pathogens, (ii) require relatively low capital investment, and (iii) easy operation and maintenance. In order to minimize the failure risk of this system, three major elements should be taken in consideration: (i) management of dredged sediments and plants, (ii) vegetation and plants control, and (iii) public acceptance and cooperation. It can be recommended, therefore, that the constructed in-stream wetlands system would enhance water quality treatment to meet the requirements of Egyptian Law 48/1982.

\section{REFERENCES}

Abdel Ghaffar, E. and El-Saadi, A. (2007) Wastewater natural treatment using multi-criteria decision analysis technology. In: Eleventh Inter-Water Technology Conf. IWTC 11pp. 115-128.

Abdel-Wahaab, R. (1995) Wastewater treatment and reuse: environmental health and safety considerations. Inter. J. Environ. Health Res. 5: 2-13.

Abdel-Satar, A. M. (2005) Water quality assessment of River Nile from Edfo to Cairo. Egypt. J. Aquatic Res. 31: 200223.

Abdulla, H.; Khafagi, I; Abd El-Kareem, M.; and Dwedar, A. (2007) Bacteriophages in engineering wetlands for domestic wastewater treatment. Res. J. Microbiology. 2:889-899.

Abu-Zeid, M. (1992) Water resource assessment of Egypt. Cand. J. Development Studies. Special Issue;173-194.

APRP (2002) Survey of Nile System Pollution Sources. In: Agric. Policy Reform Program. Water Policy Activity. Task Order 22, Report No. 64. Sept. 2002, pp 1-72.

Badr, M. H., Elewa, A., Shehata, M. B., Mohamed, 1. F., and Abdelaziz, G. S. (2006) Studies on the effect of ElRahawy drain on the River Nile water pollution by trace elements and major cations at El-Kanater El-Khayria area under the effect of seasonal variation. Ass. Univ. Bull. Res. 9: 35-54.

Ball, J. (1939) Contribution to The Geography of Egypt. Cairo, Government Press. Bulaq.

Bouwer, H. (2002) Integrated water management for the $21 \mathrm{st}$ Century: problems and solutions. J. Irrig. Drainage Engin. 128: 193-202.

DRI (1995) Reuse of drainage water in the Nile Delta, monitoring, modeling and analysis. Final Report. Drainage Water Institute, NWRC., Cairo. 
DRI (2000) Monitoring and analysis of drainage water quality project. MADWQ Final Report. Drainage Research Institute. NWRI, Egypt.

Dybern, B. I. (1974) Water Pollution. A problem with global dimensions. AMBIO 3: 139-145.

El- Bouraie, M. M., El-Barbary, A. A., Yehia, M. M., and Motawea E. M. (2010) Heavy metals concentration in surface Nile water and bed sediments at Nile Delta in Egypt. Suo. 61: 1-12, Suoseura- Finish Peatland Society, Helsinki 2010.

Elewa, H. H. (2010) Potentialities of water resources pollution of the Nile River Delta, Egypt. The Open Hydrlogy J. 4: 113.

El-Gamal, A. and Shafik, Y. (1985) Monitoring of pollutants discharging to the River Nile and their effect on river water quality. Water Quality Bulletin, WHO, Environmental Canada. Vol.(10) No(3): 111-115 and page 161.

El-Gamal, H. A., and El-Shazely, H. S. (2008) Water quality management scenarios in Rosetta River Nile Branch Egypt. Twelfth Inter. Water Tech. Conf. IWTC 12. Alexandria, Egypt. Pp. 901-908.

Elsokkary, I. H. (1992) Trace elements in sediments and waters: Case study from Egypt. In: "Impact of Heavy Metals in the Environment". Ed. Vernet, J. P., Elsevier, Amsterdam. Pp 355-379.

Elsokkary, I. H. and AbuKila, A. F. (2011) Water quality evaluation of El-Umoum Drain, west Nile Delta of Egypt during the period 1989-2010. Alex. Sci. Exchange J. 32: 453:466.

EWPR (2003) Nile River Water Quality Management study. In: Egypt Water Policy Reform. Task Order 815 Report No. 67, June 2003, pp1-93.

FAO (1992) Wastewater Treatment and Use in Agriculture. Food and Agriculture Organization. Irrigation and Drainage paper 47 . Rome. Italy.

Farag, H., and Donia, N. (2006) Spatial modeling approach to water pollution monitoring of drainage system (ElFayoum). Tenth. Inter. Water Technology Conference. IWTC 10. Alexandria, Egypt. Pp. 1163-1171.

GEF (2005) Improving water quality of lake manzala. Global Environmental Facility. Jan. 2005 (www. the GEF. Org).

GEF/ UNDP (2009) Demonstrating the suitability of using engineered wetlands as a low-cost alternative for treating sanitary sewage. GEF/UNDP- Lake Manzala Engineered Wetlands project (LMEWP).

Hammer, D. A. (1990) Constructed Wetlands for Wastewater Treatment. Chelsea, MI. Lewis Publishers, Inc.

Hammer, D. A. (1997) Creating Freshwater Wetlands. $2^{\text {nd }}$ Edition, CRC. Lewis Publishers, Inc.

Kelley, R. and Welsh, J. (1992) Egypt Water Quality Management Action Plan, Phase 2. A study submitted to USAID/Egypt and the Government of Egypt, Cairo.
Khan, H.; Dawe, P.; Paterson, R.; and Abdel-Gawad, S. (2011) Water resources management system for Nile River. 2011 Inter. Conf. on Environ. Sci. and Engineering. IPCBEE. Vol. 8: 308-312. IASIT Press, Singapore.

Masi, F; El-Hamouri, B.; Abdel Shafi, H.; Baban, A.; Garbi, A; and Regelsberger, M (2010) Treatment of segregated black/gray domestic wastewater using constructed wetlands in the Mediterranean basin: the zero-m experience. Water Sci. Technol. 61:97-105.

Meybeck, M. (2005) Looking for water quality. Hydrol. Process. 19:331-338.

Mitsch, W. J., and Gosselink, J. G. (2000) Wetlands. $3^{\text {rd }}$. Edition. John Wily\&Sons. New York.

Mitsch, W.J. (1993) " Landscape design and the role of created, restored and natural riparian wetlands in controlling nonpoint source pollution" In: Created and Natural Wetlands for Controlling Nonpoint Source Pollution. Eds. R. K. Olson, Us EPA Office of Res. And Development and Office of wetlands. Oceans and wetersheds.

Nagy, H. M. and Salem, A. AS. (2003) Evaluation of Drainage water quality for reuse - A case study of the Umoum drain in Egypt. Lowland Tech. Inter. 5: 27-38.

NRI(2008) Nile Water Quality Status During 2007. Nile Research Institute. National Water Research Center (NWRC) Ministry of water Resources and irrigation. Feb. 2008.

NWRC(2000) National water Resources Plans for Egypt, Water Quality and Pollution Control. Technical Report No.5., National Water Research Center, WL/DELFT. Hydraulics, 2000.

RNPDP (1995) Environmental Pollutions and Legislative Regulations: Law 48/1982 and Decree 8/1983. Aug. 1995, River Nile Protection and Development Project NWRCMPWWR-CIDA. Project No. 344/17564, Candian Exceuting Agency.

Saad, S; Zaghloul, N.; Schwaiger, P. K.; and de Villeneuve, P. H. (2011) Towards a lake Nasser management plan: Results of pilot test on integrated water resources management. In: Fifteenth Inter. Water. Tech. Conf. IWTC-15 pp. 1-12.

Stott, R.; Jenkins, J.; Bahgat, M.; and Shalaby, I. (1999) Capacity of constructed wetlands to remove parasite egs from wastewater in Egypt. Water Sci. Technol. 40: 117123.

Trattner, R. B. and Woods, S. J. E. (1989) The use of wetland systems for municipal wastewater treatment. Encyclopedia of environmental Control Technology. Vol. 3. Wastewater Treatment Technology.pp 591-622.

UNESCO (1983) Law 48/1982, Regulating the Protection of the River Nile. $6^{\text {th }}$ year Nos. 3 and 4 . Periodical bulletin published by MAB National Commission for UNESCO. Dec. 1983, Cairo, Egypt.

Wahaab, R. A. and Badawy, M. I. (2004) Water quality assessment of the River Nile System: An overview. Biomedical Environ. Sci. 17:87-100. 
Welsh,J. and Mancy, K. (1992) Egypt Water Quality Impact Assessment. Phase 1, A study submitted to USAID/Egypt and the Government of Egypt, Cairo.

Wetzel, R. G. (1993) Constructed wetlands: scientific foundations are critical. In: Constructed Wetland for Water Quality Improvement. Ed., Gerarld A. Moshiri. Boca Raton, F1. Lewis publishers, Inc.
Whittington, D. and Guariso, G. (1983) Water Management Models in Practice: A case Study of the Aswan High Dam. Elsevier Sci. Pub. Comp. Amsterdam.

WHO (1989) Health guidelines for the use of wastewater in agriculture and aquaculture. Tech. Bull. Ser. 77, WHO Geneva, Switzerland.

Zidan, A. A; Abdel Gawad, S. T.; Moharram, S. H., and Rashed, A. A. (2005) Estimation of pollutants by PREWet Model for surface flow constructed wetland in Egypt. Mansoura Engineering J. 30(3) 1-12. 


\title{
الملخص العربي
}

\section{التوقع المأمول للاستخدام الآمن لمياه الصرف الزراعى فى الرى}

\author{
ابراهيم حسين السكرى، علاء فاروق ابو كيله
}

وعلى الجانب الأخر كان تركيز الأكسجين المستهلك الكيميائى مرتفعا في مياه فرعى دمياط ورشيد لدلتا النيل وقد وجد التح ان مياه

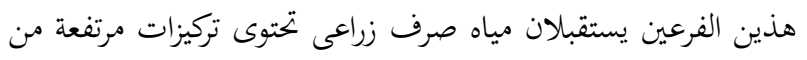
الملوثات العضوية والغير عضوية وكذلك الحيوية المسببة للأمراض.وقدوجد ان المصادر الرئيسية للتلوث هى المصارف الصغيرة

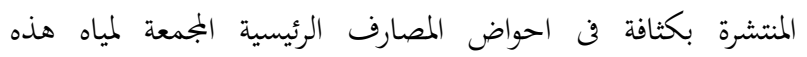

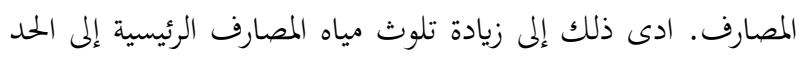
الغير مسموح به لأجراء عمليات الخلط مع المياه العذبة للترع الرئيسية. ولكى يجرى تحسين لنوعية مياه المصارف الرئيسية يجب معالجة مياه لمياه المصارف الصغيرة. ونظرا لعدم امكانية انشاء معالجة تقليدية لمياه

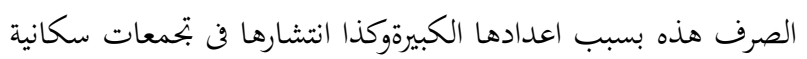

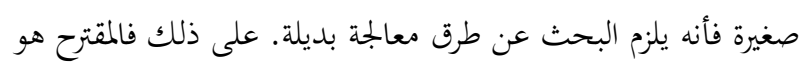

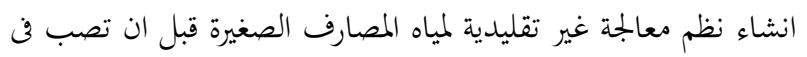
المصارف الرئيسة. و يعتبر نظام الأرض الرطبة للمعالجة هو الأكثر

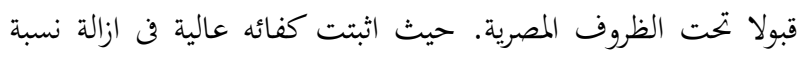

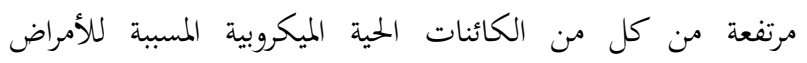

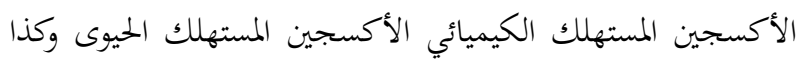
زيادة تركيز الأكسجين الذائب. ويمتاز نظام الأرض الرطبة لمعالجة المياه

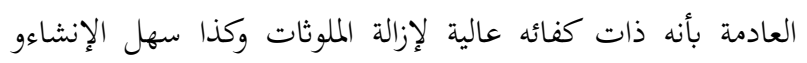
التركيب والصيانة كما انه لا يحتاج إلى رأس مال كبير حيث الانهاته انه منخفض التكلفة.
يعتبر غر النيل المصدر الرئيسى للمياه العذبة في مصر .وقد حددت

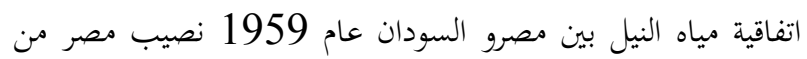

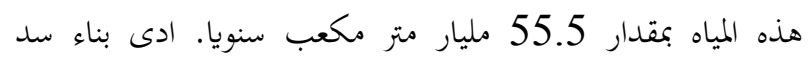

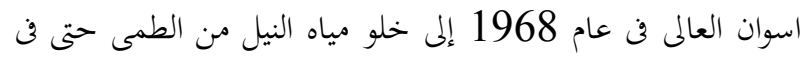

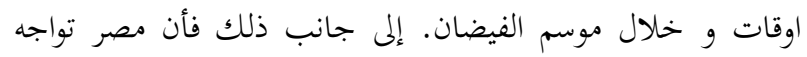

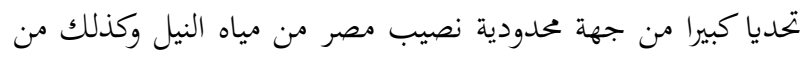

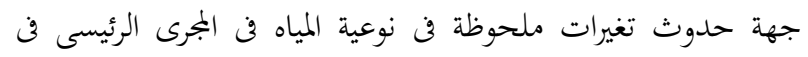
الوادى و في الدلتا.ويعزى ذلك إلى ادخال التصرفات السائلة في مياه

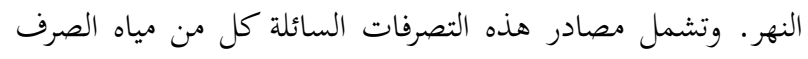
الزراعوكذلك المخلفات السائلة لأنشطة المنزليةولأنشطة الصناعية.وقد واجهت الحكومة المصرية هذا التحدى بإصدار قانون 48 لعام 1982وكذلك المرسوم رقم 8 لعام 1983 بهدف حماية مياه غر النيل و المجارى المائية من التلوث. تشير نتائج الدراسات التى رقات

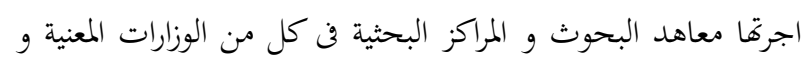

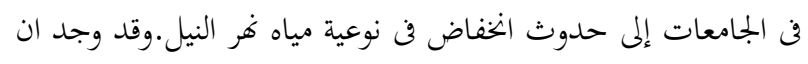

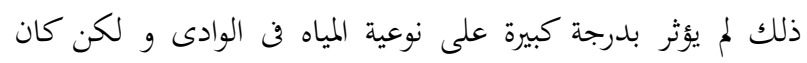

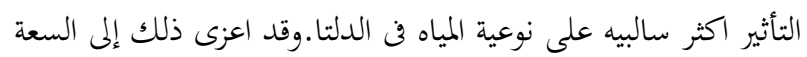

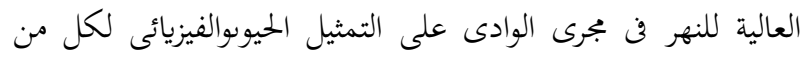

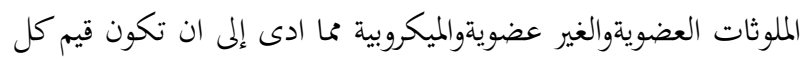
من تركيز الأكسجين الذائب والأكسجين المستهلك الكيميائى والأكسجين المستهلك الحيوى وكذا عدد بكتريا القولون متوافقة مع الحين معايير قانون 1982/48وكذا المرسوم رقم 1983/8. 